\title{
Trends in commuting time of European workers: A cross-country analysis
}

\author{
José Ignacio Giménez-Nadal ${ }^{\mathrm{a}, \mathrm{b}, *}$, José Alberto Molina ${ }^{\mathrm{a}, \mathrm{b}, \mathrm{c}}$, Jorge Velilla ${ }^{\mathrm{a}, \mathrm{b}}$ \\ ${ }^{\text {a } U n i v e r s i t y ~ o f ~ Z a r a g o z a, ~ S p a i n ~}$ \\ ${ }^{\mathrm{b}}$ IEDIS, University of Zaragoza, Spain \\ ${ }^{\mathrm{c}}$ IZA, Germany
}

\section{A R T I C L E I N F O}

JEL classification:
R40
O57
Keywords:
Commuting time
European working conditions survey
Trends
Gender gap
Socio-demographic factors

\begin{abstract}
A B S T R A C T
This paper examines the time spent commuting to/from work by workers in fifteen European countries, during the last three decades, with the aim of analyzing recent trends in commuting and the factors affecting commuting behavior. Using data from several waves of the European Working Conditions Survey, results show a significant gender gap in commuting time in Austria, Belgium, France, Germany, Italy, Ireland, Luxembourg, the Netherlands, and the UK, with male workers devoting more time to commuting than their female counterparts. We further explore the factors related to commuting time, documenting a level of heterogeneity in commuting behavior as certain determinants of commuting time differ across countries. By analyzing the evolution of commuting time in Europe in recent decades, and the associated factors, our analysis may serve to guide future planning programs.
\end{abstract}

\section{Introduction}

Many millions of workers spend time travelling on their working days, and commuting to/from work is one of the most important trips in their working days. One-fifth of workers in Europe spend more than 90 min commuting each day, equivalent to about $29 \mathrm{~km}$ (SD Worx, 2018) distance. The European Parliament Resolution of December 2, 2015 on Urban Mobility (2014/2242 (INI)) reflects the demographic forecast, that by 2050 up to $82 \%$ of EU citizens will reside in urban areas other than their workplaces. The mobility of the European population is primarily based on the use of private vehicles ( $50 \%$ use private vehicles daily, while only $16 \%$ use public transport and $12 \%$ use bicycles), such that daily commuting generates around $25 \%$ of $\mathrm{CO} 2$ emissions in Europe. The European Resolution places special emphasis on the many adverse health effects of the current mobility model, and tasks local governments with taking the necessary measures to improve the quality of life of the population, promoting changes towards healthy and sustainable mobility modes, in accordance with WHO guidelines. Thus, European countries need to consider new approaches to daily mobility planning, by promoting healthier systems that encourage higher levels of well-being of the population and that are more economically, socially, and environmentally sustainable.

Given its importance, commuting to/from work plays a central role in daily mobility planning, and thus the analysis of commuting behavior is important for the correct design of mobility policies. Commuting time has been extensively studied in the past, and some level of consensus has been achieved from different settings.

For instance, commuting time has been linked to certain negative outcomes. Hansson et al. (2011) and Kunn-Nelen (2016) found a negative correlation between commuting and health outcomes in Sweden and the UK, respectively. Roberts et al. (2011), and Dickerson et al. (2014) reported lower subjective and psychological wellbeing of workers who commute longer in the UK. Similarly, Kahneman et al. (2004) and Kahneman and Krueger (2006) found that commuting ranks among the lowest activities in terms of "instant enjoyment", using time use data from the US; and several authors have found that commuting is associated with increased stress (Gottholmseder et al., 2009; Wener et al., 2003; Frey and Stutzer, 2008; Novaco and Gonzalez, 2009). Commuting has also been linked to increases in labor costs and losses in productivity (Allen, 1983; Grinza and Rycx, 2020), with increased commuting leading to shirking behavior and increased sickness absenteeism (Ross and Zenou, 2008; Van Ommeren and Gutiérrez-i-Puigarnau, 2011; Goerke and Lorenz, 2017; Gimenez-Nadal et al., 2018b). The impact of commuting on wages has also received some attention in the literature and, in general, higher wages are associated with longer commutes (e.g., Leigh, 1986; Crane, 2007; Ross and Zenou, 2008; Ruppert et al., 2009; Mulalic et al., 2014).

Regarding trends in commuting and the factors affecting commuting,

\footnotetext{
* Corresponding author. Department of Economic Analysis, Faculty of Economic and Business Studies, C/ Gran Vía 2, 50005 Zaragoza, Spain.

E-mail addresses: ngimenez@unizar.es (J.I. Giménez-Nadal), jamolina@unizar.es (J.A. Molina), jvelilla@unizar.es (J. Velilla).
} 
prior research has documented increasing trends in commuting time during recent years in the US (Kirby and LeSage, 2009; McKenzie and Rapino, 2009; Gimenez-Nadal, Molina and Velilla, 2018a), Germany (Gimenez-Nadal and Molina, 2014), and the Netherlands (Susilo and Maat, 2007). Furthermore, education has been found to be positively correlated to commuting, as highly educated workers may search for more specialized jobs, which can require commuting longer distances (Rouwendal and Nijkamp, 2004; Sandow and Westin, 2010; Dargay and Clark, 2012). Urban structure and geographic characteristics of work and housing locations have also been found to be important determinants of commuting, in different settings (Cropper and Gordon, 1991; Naess and Sandberg, 1996,2005; Manning, 2003; Rouwendal and Nijkamp, 2004; Susilo and Maat, 2007; Deding et al., 2009; Sandow and Westin, 2010; McQuaid and Chen, 2012, Naess et al., 2019a,2019b).

But despite interest in the analysis of commuting, most of the existing literature has focused on single countries. The analysis of several countries at once, with harmonized and comparable information, may serve to draw general patterns and differential factors, with the aim of guiding transport policies. In that context, this paper explores how commuting time has evolved during the last three decades, using data from the European Working Conditions Survey (EWCS) for Austria, Belgium, Denmark, Finland, Germany, Greece, France, Ireland, Italy, Luxembourg, the Netherlands, Portugal, Spain, Sweden, and the United Kingdom. Our results suggest that, in general terms, commuting has increased during the period in Denmark, Finland, Sweden, Ireland, Italy, Spain, Belgium, France, and the Netherlands. Conversely, we find decreasing trends in commuting time in Austria, Germany, Greece, and Portugal.

We also analyze the existence of gender gaps in commuting time, and how they have evolved. The analysis of the gender gap in commuting is recurrent, finding in many settings that male workers commute more (time/distance) than their female counterparts (Hanson and Johnston, 1985; White, 1986; van Ommeren and van der Straaten, 2008; Hjorthol, 2008; Sandow, 2008; Sandow and Westin, 2010; Scheiner, 2010,2017; Roberts et al., 2011; Dargay and Clark, 2012; McQuaid and Chen, 2012; O'Kelly et al., 2012; Scheiner and Holz-Rau, 2012; Gimenez-Nadal and Molina, 2014, 2016; Hjorthol and Vågane, 2014). However, this gender difference can be small or insignificant in some countries (van der Berg and Gorter, 1997; Doyle and Taylor, 2000; Gossen and Purvis, 2005; Vandersmissen et al., 2006; Albert et al., 2019), and thus identifying the countries with the highest or lowest gender gaps in commuting can be important for policy issues. The analysis of gender differences in commuting is of interest, given that it may lead to differences in well-being and health between male and female workers, and could even explain the wage gender gap (Le Barbanchon et al., 2019). We find significant gender differences in commuting time in Anglo-Saxon and Continental countries, but not in Nordic and Mediterranean countries. Furthermore, such gender gaps have increased during recent years in Ireland, Italy, Belgium, and France.

Further, we study the determinants of commuting time during the 2010 s, for each of the countries in the sample, finding a certain degree of heterogeneity in the determinants of commuting time, depending upon the country examined, in terms of sociodemographic, labor, household, and occupation attributes of workers. This heterogeneity suggests that commuting time is, at least at the individual level, a complex process that may depend on several unobservable or stochastic factors, at least at the individual level. We find that better road infrastructures seem to reduce commuting times, the generalized use of the car as a means of transport (higher motorization rates) is related to higher average commuting, and unemployment rates and GDP are also related to commuting times. These results reveal complex relationships between commuting time and a range of country characteristics that should be examined in future research on commuting time.

The contributions of the paper are threefold. First, we provide a descriptive study of commuting over time, using harmonized data for fifteen European countries, with the aim of identifying which countries have done better in terms of reducing commuting time of workers. If we can identify those countries that have succeeded in reducing commuting, future research can focus on these countries and analyze their transport and planning policies. Second, we contribute to the debate on the gender gap in commuting time, showing that it is not a generalized fact. Identifying which countries present a significant gender gap in commuting may help to drive analysis of the factors underlying this gap. Occupational sorting, female household responsibilities, gender norms, and/or availability of public transport, may all play important roles in this explanation. Third, we gather information on the factors that contribute to more or less time in commuting. Although we find a certain degree of heterogeneity in the determinants of commuting time, in terms of sociodemographic, labor, household, and occupational attributes of workers, we also find that better road infrastructures, higher unemployment rates and per-capitaGDP are related to shorter average commuting times, while higher motorization rates are related to longer average commuting times.

The remainder of the paper is organized as follows. Section 2 describes the data used in the empirical analysis. Sections 3 and 4 present general trends in commuting times and in the commuting gender gap in Europe during the 1995-2015 period, respectively. Section 5 analyzes the determinants of commuting time, and Section 6 analyzes how country-level factors relate to the time devoted to commuting. Section 7 discusses future research on commuting, and Section 8 concludes.

\section{Data and variables}

We use data from the European Working Conditions Survey (EWCS), for the years 1995, 2000, 2005, 2010, and 2015. The EWCS is a crosssectional micro-database, conducted every five years by Eurofound since $1990 .{ }^{1}$ The EWCS is based on stylized questionnaires, and includes information for the 28 European Union members, along with the five candidate countries (Albania, Macedonia, Montenegro, Serbia, and Turkey), Switzerland, and Norway. The main purpose of the EWCS is to provide researchers and institutions with harmonized and cross-country information about the conditions of workers in their respective workplaces. ${ }^{2}$ The EWCS includes specific sociodemographic information on sampled individuals.

The sample is restricted to workers in countries with information on all the years covered by the EWCS. As we are interested in employed and self-employed workers, which comprises working-age individuals, we retain in the sample respondents between 16 and 65 years old (inclusive) who report being either employees or self-employed. Workers with missing information on the relevant variables (commuting time, and

\footnotetext{
1 See https://www.eurofound.europa.eu/es/surveys/european-working-con ditions-surveys. Years 2000 and 2001 correspond to the 3rd EWCS wave. All the countries of the sample used throughout the analysis correspond to the year 2000 within the 3rd EWCS wave. Data from the 1990 EWCS is not used in the analysis, given that there is no information on commuting time.

2 We have, alternatively, done all the analysis using the European Quality of Life Survey (EQLS) for the year 2016. If we compare these results with the main results shown in the manuscript, we observe that commuting times and the gender gap in commuting time is consistent across countries, with the only exceptions being the Netherlands and Germany for the time devoted to commuting time, and Finland and Spain for the gender gap in commuting. Results are available upon request. An alternative source is the National Travel Survey, where information on commuting is also available. But given that the comparison of commuting behavior over time and across countries is the main objective of our analysis, the use of these surveys is not recommend, given that, as argued by Ahern et al. (2013), "comparability might be limited or even impossible due to the application of distinct methodological approaches based on varying concepts (e.g. the definition of what is regarded as trip), differing data collection times (e.g. workday coverage vs. 7 day week), specific national conditions (e.g. availability of sampling frames etc.) or the prevailing law (e. g. data protection regulations, privacy policy)".
} 
socio-demographic and occupational characteristics) are also omitted. This leaves 87,869 individuals in the sample, corresponding to the following countries: Austria, Belgium, Denmark, Finland, Germany, Greece, France, Ireland, Italy, Luxembourg, the Netherlands, Portugal, Spain, Sweden, and the United Kingdom (See Table A1 in Appendix A for a summary of sample sizes, by country and year.).

Commuting time in the EWCS is defined as two-way commuting time, and is measured in minutes per day from the following question: "In total, how many minutes per day do you usually spend travelling from home to work and back?". ${ }^{3}$ It is important to acknowledge that time is, in general, more accurate than distance in measuring commutes, which reduces the error term, and collects some aspects that distances do not capture, such as traffic density, accessibility, and speed of commutes (Van Ommeren and Van der Straaten, 2008; Jara-Díaz and Rosales-Salas, 2015; Gimenez-Nadal, Molina and Velilla, 2018a). ${ }^{4}$

For the analysis of commuting time, the five waves of the EWCS are divided into the decade of the 1990s (i.e., the 1995 wave), the decade of the 2000s (the 2000 and 2005 waves), and the decade of the 2010s (the 2010 and 2015 waves). We follow Aguiar and Hurst (2007), and Gimenez-Nadal and Sevilla (2012), and use demographic weighting, as proposed by Katz and Murphy (1992), to report the cross-country trends in commuting time. Details for the demographic weights, computed in terms of the original sample weights and the demographic composition of the sample, are shown in Appendix B.

\section{Trends in commuting time}

We analyze the evolution of commuting time over the last three decades in Europe. Table 1 includes the average commuting time, using demographic weights, by country and survey of the EWCS, along with robust standard errors. Errors are computed by regressing, for each country, commuting time in terms of three dummies representing the three decades considered in the sample, with no constant term to avoid over-identification. We also report the raw differences for the comparison between the 1990s and the 2000s, the 2000s and the 2010s, and the 1990s and the 2010s, along with $t$-test $p$-values for the statistical significance of these differences, to analyze whether there has been a statistically significant increase/decrease in commuting time. Countries are grouped according to their similarities in their social welfare regimes, that is Nordic countries (Denmark, Finland and Sweden); Anglo-Saxon countries (Ireland and the United Kingdom); Mediterranean countries (Greece, Italy, Portugal and Spain); and Continental countries (Austria, Belgium, France, Germany, Luxembourg and the Netherlands). ${ }^{5}$ A summary of the results is shown below, and additional results are shown in Table 1:

- Denmark, Finland, and Sweden (Nordic countries): 1990s-2000s stable; 2000s-2010s increase; 1990s-2010s increase.

- Ireland and the UK (Anglo-Saxon countries): 1990s-2000s decrease; 2000s-2010s increase; 1990s-2010s increase.

- Greece and Portugal: 1990s-2000s decrease; 2000s-2010s decrease; 1990s-2010s decrease.

- Italy: 1990s-2000s increase; 2000s-2010s decrease; 1990s-2010s increase.

- Spain: 1990s-2000s stable; 2000s-2010s increase; 1990s-2010s increase.

\footnotetext{
${ }^{3}$ The evolution of the question for commuting time in the EWCS surveys is shown in Table A2 in Appendix A.

${ }^{4}$ A potential limitation of this study relies on the fact that commutes are defined in terms of a stylized question, where respondents are asked for the time they usually spend commuting. Commuting time measured from time use diaries may be more reliable (Robinson, 1985; Bonke, 2005; Yee-Kan, 2008).

5 See Table A5 in Appendix A for the classification of countries in different clubs, according to their social welfare regimes.
}

- Austria: 1990s-2000s decrease; 2000s-2010s increase; 1990s-2010s stable.

- Luxembourg: all stable.

- Germany: 1990s-2000s decrease; 2000s-2010s increase; 1990s-2010s decrease.

- The Netherlands: 1990s-2000s decrease; 2000s-2010s increase; 1990s-2010s increase.

- Belgium and France: 1990s-2000s stable; 2000s-2010s increase; 1990s-2010s increase.

In summary, trends for some of the countries considered in this study are consistent with prior research, which has documented increasing trends in commuting in Germany during the 1991-2001 period (Gimenez-Nadal and Molina, 2014) and the Netherlands between 1993 and 2005 (Susilo and Maat, 2007). Commuting time has decreased over the analyzed period in Greece, Portugal, and Germany, which makes these three countries examples to be analyzed for the reduction of commuting time. Our results indicate that further research is required to understand cross-country differences in both the level and evolution of commuting time.

\section{The gender gap in commuting time}

Prior research has documented the existence of a statistically significant gender gap in commuting time in Canada (Mok, 2007), France (Le Barbanchon et al., 2019), Ireland (Moss et al., 2004; O'Kelly et al., 2012), Korea (Lee and McDonald, 2003), Spain (Albert et al., 2019), Sweden (Sandow, 2008; Sandow and Westin, 2010), the Netherlands (van Ommeren and van der Straaten, 2008; Gimenez-Nadal and Molina, 2014; Oakil et al., 2016), the US (Kain, 1962; Hanson and Johnston, 1985; White, 1986; Turner and Niemeier, 1997; Crane, 2007; Gimenez-Nadal and Molina, 2016), and the UK (Grieco et al., 1989; Dex et al., 1995; Roberts et al., 2011; Dargay and Clark, 2012; McQuaid and Chen, 2012; Dickerson et al., 2014; Nafilyan, 2019). ${ }^{6}$ This Section focuses on the gender gap in commuting time, by analyzing the evolution of commuting time of workers, by gender, along with the trends in commuting time gender gaps. To that end, Table 2 shows the evolution of commuting time, by gender, during the 1990s, 2000s and 2010s and also reports the gender gap in commuting time, defined as the average commuting of men, minus that of women, by country and year, using demographic weighting. Countries are aggregated in four panels, analogously to Table 1 . We additionally include the difference in the commuting time gender gap between the 1990s and the 2000s, the 2000 s and the 2010s, and the 1990s and 2010s, along with the statistical significance of those differences according to t-tests. A summary of the evolution of commuting time gender gap is shown below, and additional statistics are shown in Table 2:

- Nordic countries: gender gaps in commuting time are statistically not significant at standard levels during the period analyzed. ${ }^{7}$

- Ireland: the gender gap was not statistically significant in the $1990 \mathrm{~s}$ and the 2000s. However, the commuting time of men (but not of women) increased in the 2010s, leading to a significant gender gap of about $10 \mathrm{~min}$.

\footnotetext{
${ }^{6} \mathrm{Ng}$ and Acker (2018) examined travel behaviors of workers in eight cities (Auckland, Dublin, Hanoi, Helsinki, Jakarta, Kuala Lumpur, Lisbon, and Manila), and found that women travel shorter distances than men, where the former prefer public transport modes but the latter prefer private cars.

7 This is an interesting result, as prior research has repeatedly documented significant differences in commuting time between male and female workers in the US, Germany, and the Netherlands (Roberts et al., 2011; Gimenez-Nadal and Molina, 2014, 2016).
} 
Table 1

Evolution of commuting time, 1995-2015.

\begin{tabular}{|c|c|c|c|c|c|c|}
\hline \multirow[t]{2}{*}{ COUNTRY } & \multicolumn{3}{|c|}{ AVERAGE } & \multicolumn{3}{|c|}{ DIFFERENCE } \\
\hline & 1990s & $2000 s$ & $2010 \mathrm{~s}$ & $90 s-00 s$ & $00 s-10 s$ & $90 s-10 s$ \\
\hline \multicolumn{7}{|l|}{ NORDIC } \\
\hline Denmark $(n=5,221)$ & $\begin{array}{l}38.863 \\
(1.246)\end{array}$ & $\begin{array}{l}40.191 \\
(0.857)\end{array}$ & $\begin{array}{l}47.171 \\
(0.932)\end{array}$ & 1.329 & $6.980 * * *$ & $8.309 * * *$ \\
\hline Finland $(n=5,135)$ & $\begin{array}{l}41.146 \\
(1.207)\end{array}$ & $\begin{array}{l}40.724 \\
(0.745)\end{array}$ & $\begin{array}{l}44.573 \\
(0.945)\end{array}$ & -0.423 & $3.849 * * *$ & $3.426^{* *}$ \\
\hline Sweden $(n=5,314)$ & $\begin{array}{l}38.804 \\
(1.022)\end{array}$ & $\begin{array}{l}39.319 \\
(0.767)\end{array}$ & $\begin{array}{l}46.507 \\
(1.098)\end{array}$ & 0.516 & $7.188^{* * *}$ & $7.704 * * *$ \\
\hline \multicolumn{7}{|l|}{ ANGLO-SAXON } \\
\hline Ireland $(n=4,952)$ & $\begin{array}{l}39.087 \\
(1.238)\end{array}$ & $\begin{array}{l}39.136 \\
(0.863)\end{array}$ & $\begin{array}{l}46.143 \\
(1.198)\end{array}$ & 0.050 & $7.006^{* * * *}$ & $7.056 * * *$ \\
\hline United Kingdom ( $\mathrm{n}=6,182)$ & $\begin{array}{l}46.409 \\
(1.627)\end{array}$ & $\begin{array}{l}40.448 \\
(0.915)\end{array}$ & $\begin{array}{l}49.035 \\
(0.960)\end{array}$ & $-5.961 * * *$ & $8.587^{* * *}$ & 2.626 \\
\hline \multicolumn{7}{|l|}{ MEDITERRANEAN } \\
\hline Greece $(n=5,149)$ & $\begin{array}{l}37.861 \\
(1.503)\end{array}$ & $\begin{array}{l}33.163 \\
(0.848)\end{array}$ & $\begin{array}{l}31.843 \\
(0.804)\end{array}$ & $-4.698 * * *$ & -1.320 & $-6.018^{* * *}$ \\
\hline Italy $(n=5,597)$ & $\begin{array}{l}23.615 \\
(0.925)\end{array}$ & $\begin{array}{l}32.362 \\
(0.821)\end{array}$ & $\begin{array}{l}29.977 \\
(0.685)\end{array}$ & $8.747 * * *$ & $-2.384 * *$ & $6.362^{* * *}$ \\
\hline Portugal $(n=4,901)$ & $\begin{array}{l}36.027 \\
(1.517)\end{array}$ & $\begin{array}{l}32.995 \\
(0.697)\end{array}$ & $\begin{array}{l}25.886 \\
(0.704)\end{array}$ & $-3.033^{*}$ & $-7.109^{* * *}$ & $-10.14 * * *$ \\
\hline Spain $(n=7,243)$ & $\begin{array}{l}31.673 \\
(1.160)\end{array}$ & $\begin{array}{l}32.422 \\
(0.729)\end{array}$ & $\begin{array}{l}34.550 \\
(0.577)\end{array}$ & 0.749 & $2.128^{* *}$ & $2.877^{* *}$ \\
\hline \multicolumn{7}{|l|}{ CONTINENTAL } \\
\hline Austria $(n=5,110)$ & $\begin{array}{l}37.957 \\
(1.425)\end{array}$ & $\begin{array}{l}32.829 \\
(0.774)\end{array}$ & $\begin{array}{l}35.827 \\
(0.942)\end{array}$ & $-5.128^{* * *}$ & $2.998^{* *}$ & -2.130 \\
\hline Belgium $(n=9,049)$ & $\begin{array}{l}40.285 \\
(1.422)\end{array}$ & $\begin{array}{l}40.723 \\
(0.909)\end{array}$ & $\begin{array}{l}46.743 \\
(0.616)\end{array}$ & 0.438 & $6.020 * * *$ & $6.458^{* * *}$ \\
\hline France $(n=7,398)$ & $\begin{array}{l}35.909 \\
(1.249)\end{array}$ & $\begin{array}{l}34.083 \\
(0.678)\end{array}$ & $\begin{array}{l}41.663 \\
(0.656)\end{array}$ & -1.826 & $7.580 * * *$ & $5.754 * * *$ \\
\hline Germany $(n=8,104)$ & $\begin{array}{l}49.235 \\
(0.917)\end{array}$ & $\begin{array}{l}41.961 \\
(0.789)\end{array}$ & $\begin{array}{l}44.261 \\
(0.641)\end{array}$ & $-7.273^{* * *}$ & $2.299 * *$ & $-4.974 * * *$ \\
\hline Luxembourg ( $n=3,275$ ) & $\begin{array}{l}40.720 \\
(1.617)\end{array}$ & $\begin{array}{l}38.710 \\
(1.132)\end{array}$ & $\begin{array}{l}40.387 \\
(0.858)\end{array}$ & -2.010 & 1.677 & -0.333 \\
\hline Netherlands ( $n=5,239$ ) & $\begin{array}{l}42.739 \\
(1.238)\end{array}$ & $\begin{array}{l}38.487 \\
(0.777)\end{array}$ & $\begin{array}{l}45.944 \\
(1.060)\end{array}$ & $-4.251^{* * *}$ & $7.456^{* * *}$ & $3.205^{* *}$ \\
\hline
\end{tabular}

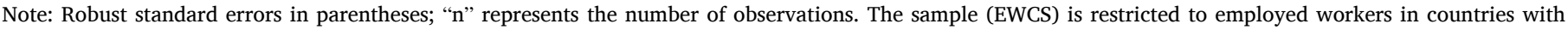

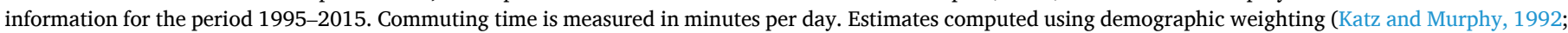

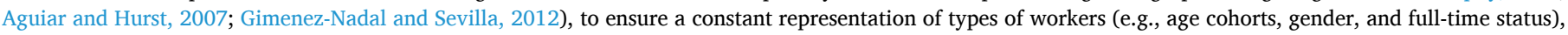
years, and countries. Reference period: 2000s.

- The UK: the gender gap has decreased from $13 \mathrm{~min}$ in the 1990s, to 9 min during the 2000s and 2010s. These gaps are statistically significant at standard levels.

- Mediterranean countries (Greece, Spain, and Portugal): gender gaps in commuting time are statistically not significant at standard levels during the period analyzed.

- Italy: the gender gap in commuting was not statistically significant in the 1990s, increased to $2 \mathrm{~min}$ in the 2000s, and to $4 \mathrm{~min}$ in the 2010s, with the latter gap being statistically significant.

- Luxembourg: the gender gap was small (about $2 \mathrm{~min}$ ) and not statistically significant in the 1990s and the 2010s. However, the gap was statistically significant during the 2000 s, where male workers commuted about 5 more minutes than women.
- Austria, Germany, and the Netherlands: gender gaps are statistically significant during all the decades. Furthermore, the differences between the 1990s and the 2010s in these gaps are not statistically significant for any of these countries.

- Belgium: the gender gap in commuting is found to be positive and significant during the 1990s, the 2000s, and the 2010s. Furthermore, there is a statistically significant increase in that gap between the 2000s and the 2010s.

- France: the gender gap is not significant during the 1990s and the 2000s, but then there is a significant increase between the 2000s and the 2010s, resulting in a statistically significant gender gap in the latter period.

To sum up, trends in the gender gap in commuting time show 
Table 2

Evolution of commuting time gender gap, 1995-2015.

\begin{tabular}{|c|c|c|c|c|c|c|c|}
\hline \multirow[t]{2}{*}{ COUNTRY } & & \multicolumn{3}{|c|}{ AVERAGE } & \multicolumn{3}{|c|}{ DIFFERENCE } \\
\hline & & $1990 \mathrm{~s}$ & $2000 \mathrm{~s}$ & $2010 \mathrm{~s}$ & $90 s-00 s$ & $00 \mathrm{~s}-10 \mathrm{~s}$ & $90 \mathrm{~s}-10 \mathrm{~s}$ \\
\hline \multicolumn{8}{|l|}{ NORDIC } \\
\hline \multirow[t]{3}{*}{ Denmark } & Women $(\mathrm{n}=2,588)$ & 38.678 & 39.910 & 46.782 & & & \\
\hline & Men $(n=2,633)$ & 38.959 & 40.353 & 47.423 & & & \\
\hline & Gap & 0.281 & 0.443 & 0.641 & 0.162 & 0.197 & 0.359 \\
\hline \multirow[t]{3}{*}{ Finland } & Women $(\mathrm{n}=2,726)$ & 41.926 & 40.885 & 45.384 & & & \\
\hline & Men $(n=2,409)$ & 40.554 & 40.574 & 43.797 & & & \\
\hline & Gap & -1.372 & -0.311 & -1.587 & 1.061 & -1.276 & 0.215 \\
\hline \multirow[t]{3}{*}{ Sweden } & Women $(\mathrm{n}=2,679)$ & 37.153 & 38.871 & 44.970 & & & \\
\hline & Men $(n=2,635)$ & 39.705 & 39.616 & 47.701 & & & \\
\hline & Gap & 2.552 & 0.745 & 2.730 & -1.807 & 1.985 & 0.178 \\
\hline \multicolumn{8}{|l|}{ ANGLO-SAXON } \\
\hline \multirow[t]{3}{*}{ Ireland } & Women $(\mathrm{n}=2,247)$ & 38.464 & 40.867 & 40.030 & & & \\
\hline & $\operatorname{Men}(\mathrm{n}=2,705)$ & 39.299 & 38.395 & 49.801 & & & \\
\hline & Gap & 0.835 & -2.472 & $9.771^{\mathrm{a}}$ & $-3.307^{c}$ & $12.244^{\mathrm{a}}$ & $8.936^{\mathrm{a}}$ \\
\hline \multirow[t]{3}{*}{ United Kingdom } & Women $(\mathrm{n}=3,047)$ & 37.269 & 34.739 & 43.142 & & & \\
\hline & $\operatorname{Men}(n=3,135)$ & 50.498 & 43.440 & 52.542 & & & \\
\hline & Gap & $13.229^{\mathrm{a}}$ & $8.701^{\mathrm{a}}$ & $9.400^{\mathrm{a}}$ & $-4.528^{\mathrm{b}}$ & 0.699 & $-3.829^{c}$ \\
\hline \multicolumn{8}{|l|}{ MEDITERRANEAN } \\
\hline \multirow[t]{3}{*}{ Greece } & Women $(\mathrm{n}=2,067)$ & 35.658 & 32.193 & 31.037 & & & \\
\hline & $\operatorname{Men}(\mathrm{n}=3,082)$ & 38.449 & 33.529 & 32.196 & & & \\
\hline & Gap & 2.791 & 1.335 & 1.159 & -1.455 & -0.177 & -1.632 \\
\hline \multirow[t]{3}{*}{ Italy } & Women $(\mathrm{n}=2,512)$ & 23.028 & 31.145 & 27.616 & & & \\
\hline & Men $(\mathrm{n}=3,085)$ & 23.774 & 32.707 & 31.234 & & & \\
\hline & Gap & 0.746 & 1.563 & $3.618^{\mathrm{a}}$ & 0.817 & $2.056^{\mathrm{c}}$ & $2.872^{\mathrm{b}}$ \\
\hline \multirow[t]{3}{*}{ Portugal } & Women $(\mathrm{n}=2,575)$ & 35.646 & 34.249 & 26.342 & & & \\
\hline & $\operatorname{Men}(\mathrm{n}=2,326)$ & 36.283 & 32.094 & 25.331 & & & \\
\hline & Gap & 0.636 & $-2.155^{c}$ & -1.012 & -2.792 & 1.144 & -1.648 \\
\hline \multirow[t]{3}{*}{ Spain } & Women $(\mathrm{n}=3,263)$ & 29.828 & 33.389 & 34.295 & & & \\
\hline & Men $(n=3,980)$ & 32.021 & 32.122 & 34.708 & & & \\
\hline & Gap & 2.193 & -1.267 & 0.413 & $-3.460^{\mathrm{b}}$ & 1.680 & -1.780 \\
\hline \multicolumn{8}{|l|}{ CONTINENTAL } \\
\hline \multirow[t]{3}{*}{ Austria } & Women $(\mathrm{n}=2,630)$ & 32.851 & 29.663 & 32.398 & & & \\
\hline & Men $(n=2,480)$ & 39.976 & 34.477 & 38.355 & & & \\
\hline & Gap & $7.125^{\mathrm{a}}$ & $4.814^{\mathrm{a}}$ & $5.956^{\mathrm{a}}$ & -2.311 & 1.143 & -1.169 \\
\hline \multirow[t]{3}{*}{ Belgium } & Women $(\mathrm{n}=4,222)$ & 36.304 & 37.814 & 41.140 & & & \\
\hline & Men $(n=4,827)$ & 41.480 & 41.927 & 49.717 & & & \\
\hline & Gap & $5.176^{\mathrm{b}}$ & $4.113^{\mathrm{a}}$ & $8.577^{\mathrm{a}}$ & -1.063 & $4.464^{\mathrm{a}}$ & $3.401^{c}$ \\
\hline \multirow[t]{3}{*}{ France } & Women $(\mathrm{n}=3,812)$ & 36.453 & 34.434 & 39.314 & & & \\
\hline & $\operatorname{Men}(\mathrm{n}=3,586)$ & 35.636 & 33.888 & 43.520 & & & \\
\hline & Gap & -0.817 & -0.546 & $4.206^{\mathrm{a}}$ & 0.271 & $4.753^{\mathrm{a}}$ & $5.024^{\mathrm{a}}$ \\
\hline \multirow[t]{3}{*}{ Germany } & Women $(\mathrm{n}=3,806)$ & 44.239 & 40.056 & 40.476 & & & \\
\hline & Men $(n=4,298)$ & 51.060 & 42.701 & 46.247 & & & \\
\hline & Gap & $6.821^{\mathrm{a}}$ & $2.644^{\mathrm{b}}$ & $5.771^{\mathrm{a}}$ & $-4.176^{\mathrm{a}}$ & $3.126^{\mathrm{b}}$ & -1.050 \\
\hline Luxembourg & Women $(\mathrm{n}=1,458)$ & 39.307 & 34.834 & 39.241 & & & \\
\hline & Men $(\mathrm{n}=1,817)$ & 41.023 & 39.790 & 40.976 & & & \\
\hline & Gap & 1.716 & $4.956^{\mathrm{b}}$ & 1.735 & 3.240 & $-3.221^{c}$ & 0.019 \\
\hline Netherlands & Women $(\mathrm{n}=2,527)$ & 36.543 & 34.292 & 39.914 & & & \\
\hline & Men $(\mathrm{n}=2,712)$ & 44.979 & 41.152 & 50.574 & & & \\
\hline & Gap & $8.436^{\mathrm{a}}$ & $6.859^{\mathrm{a}}$ & $10.660^{\mathrm{a}}$ & -1.577 & $3.801^{\mathrm{b}}$ & 2.224 \\
\hline
\end{tabular}

Note: "n" represents the number of observations. The sample (EWCS) is restricted to employed workers in countries with information for the period 1995-2015. Commuting time is measured in minutes per day. Average commutes are computed using demographic weighting (Katz and Murphy, 1992; Aguiar and Hurst, 2007; Gimenez-Nadal and Sevilla, 2012), to ensure a constant representation of types of workers (e.g., age cohorts, gender, and full-time status), years, and countries. Gaps are defined as the average for men, minus the average for women.

a Significant at the $99 \%$.

b Significant at the $95 \%$.

c Significant at the $90 \%$, according to t-type tests. 
different pictures for the groups of countries considered. While for Nordic and Mediterranean countries there seem to be non-significant gender gaps, results for Ireland, the UK, Austria, Belgium, France, Germany, and the Netherlands show statistically significant differences between male and female workers in terms of commuting behaviors. Indeed, in all of these countries, male workers commute for longer than their female counterparts, with the largest differences being in the Netherlands during the 2010s (about $11 \mathrm{~min}$ ) and the UK during the 1990s and the 2010s (13 and 9 min respectively). Furthermore, although the gender gap in commuting time has decreased in the UK, it has increased in Ireland, Italy, Belgium, and France.

\section{The factors associated with commuting time}

We now explore how socio-demographic factors are associated with commuting time in the fifteen European countries considered. The EWCS data allows us to define certain variables that may be correlated with commuting time. Characteristics such as education, marital status, and the presence of children at home have been shown to be related to the commuting behavior of workers, although some of these variables are not defined for all the waves of the EWCS. For instance, education, and household composition (e.g., presence of children) are not available for the 1990s and the 2000s. As a consequence, this part of the analysis is restricted to the 2010s decade (2010 and 2015).

We consider the gender of individuals with a dummy variable that takes value 1 if respondents are males, and 0 if they are females. The analysis shown in the previous Section indicates that gender may be an important factor in some countries. We also consider the age of respondents, measured in years. The EWCS includes information about the household composition of respondents, including the presence of others in the household, their ages, gender, and the relationship with the respondent. ${ }^{8}$ We use this information to define, first, the presence of a married or unmarried partner of the respondent, as these workers usually commute longer time/distance, relative to single workers (Roberts et al., 2011; McQuaid and Chen, 2012; Gimenez-Nadal, Molina and Velilla, 2018a). In doing so, we define a dummy variable that takes value 1 for individuals who live with a married/cohabiting partner, and value 0 for single workers. Second, we identify the number of children in the household, which is set to zero for respondents without children. The number of children may be an important variable to take into account while analyzing commuting time, as prior research has shown commuting time may be linked to childcare responsibilities, especially among women (Hanson and Johnston, 1985; Lee and McDonald, 2003; McQuaid and Chen, 2012; Gimenez-Nadal and Molina, 2016).

We also consider the maximum level of education achieved by individuals. Highly educated individuals (i.e., white collar workers) may search for more specialized jobs and, therefore, their commuting behaviors may differ from their lower educated counterparts (Ross and Zenou, 2008; Gimenez-Nadal et al., 2018b). The EWCS defines education in terms of 7 codes, including: 0) "pre-primary education", 1) "primary education or first stage of basic education", 2) "lower secondary or second stage of basic education", 3) "(upper) secondary education", 4) "post-secondary non-university education" 5) "first stage of university education", and 6) "second stage of university education". In our caseb, we define three dummies. Primary education takes value 1 for individuals whose education category is 0 or 1 ( 0 otherwise); secondary education takes value 1 for individuals whose category is 2,3 or 4 ( 0 otherwise); and University education takes value 1 for individuals

\footnotetext{
${ }^{8}$ Information about the relation with the respondent includes the following categories: 1) "Spouse/partner"; 2) "Son/daughter of respondent or cohabiting partner"; 3) "Parent, step-parent or parent in law"; 4) "Daughter or son-in-law"; 5) "Grandchild"; 6) "Brother/sister (including half- and step-sibling)"; 7) "Other relative"; 8) "Other non-relative". Spouses and unmarried partners are identified from category (1), and children are identified from category (2).
}

whose education category is 5 or 6 ( 0 otherwise).

We define certain labor attributes of workers. Specifically, as selfemployed workers have been found to have different commuting behaviors than employees (Van Ommeren and Van der Straaten, 2008; Gimenez-Nadal, Molina and Velilla, 2018a; Albert et al., 2019), we define a dummy that takes value 1 for the self-employed, and 0 for employees. We also define a dummy that takes value 1 for full-time workers ( 0 for their part-time counterparts), as workers may not be willing to commute longer distances for short work schedules. Furthermore, the EWCS includes information about the occupation of workers, defined in terms of the International Standard Classification of Occupations (ISCO) 88 (1 digit) codes, which has been found to be linked to worker commuting behavior (Hanson and Johnston, 1985; Gordon et al., 1989). This classification identifies 10 types of occupations: 0) "armed forces"; 1) "managers"; 2) "professionals"; 3) "technicians and associated professionals"; 4) "clerical support workers"; 5) "service and sales workers"; 6) "skilled agricultural, forestry, and fishery workers"; 7) "craft and related trades workers"; 8) "plant and machine operators, and assemblers"; and 9) "elementary occupations". 9

Summary statistics of commuting time and socio-demographic characteristics are shown in Table A3 in Appendix A, by country. Regarding commuting time, countries can be grouped in four clusters, according to a k-medians cluster analysis. The first cluster is composed of Italy and Portugal, with average commuting times of 29.1 and 29.5 min per day. The second cluster is formed of Austria, Greece and Spain, with average commuting times between $33.8 \mathrm{~min}$ per day and $35.7 \mathrm{~min}$ per day. France and Luxembourg constitute the third cluster, with average commutes of 38.6 and 39.0 min per day, respectively. That leaves Belgium, Denmark, Finland, Germany, Ireland, the Netherlands, Sweden, and the UK in the fourth cluster, with commuting times well above 40 min per day. Within this group, Denmark shows the lowest average daily commute at $42.2 \mathrm{~min}$, while the United Kingdom is the country where workers have the longest commute, according to the sample, with an average $45.6 \mathrm{~min}$ per day. ${ }^{10}$

\subsection{Empirical strategy}

Let $k=1, \ldots, 15$ represent each of the countries considered for the analysis. We estimate the following equation, by Ordinary Least Squares (OLS), by country ${ }^{11}$

$C_{i k}=\beta_{0 k}+\beta_{1 k} S_{i k}+\beta_{2 k} F_{i k}+\beta_{3 k} L_{i k}+\alpha+\varepsilon_{i k}$,

where, for each individual " $i$ " and omitting the sub-index $k$ that identifies countries, $C_{i}$ represents commuting time, $S_{i}$ represents the sociodemographic attributes of " $i$ " (gender, age, education), $F_{i}$ represents household variables (the presence of a partner, family size, the number of children under 5 years, and the number of children between 5 and 17 years), $L_{i}$ represents the labor attributes of " $i$ " (being a self-employed worker, full-time status, occupation), and $\varepsilon_{i}$ represents unmeasured

\footnotetext{
${ }^{9}$ Despite that the EWCS includes information about the urban/rural status of the region where respondents reside, it is only available for 2015, and thus we do not include this characteristic in the analysis. This characteristic has been found to be a significant predictor of commuting (see, e.g., Hamilton, 1982, 1989; Gordon et al., 1989; Cropper and Gordon, 1991; Small and Song, 1992; Mieszkowski and Mills, 1993; Kahn, 2000; Van Ommeren and Van der Straaten, 2008; Gimenez-Nadal, Molina and Velilla, 2018a).

${ }^{10}$ The analysis includes individuals who may work from home and report zero commuting time, including home-based workers and telecommuters. In our sample, $4.83 \%$ report zero commuting, a magnitude well below the US (about 13\%, according to Gimenez-Nadal, Molina and Velilla, 2019). See Table A4 in the Appendix for a summary of zero commuters, by country.

11 Additional estimates with the pooled sample, where standard errors are clustered at the country level, are available upon request. Results are robust to this alternative specification.
} 
factors. Estimates include demographic weights, and standard errors are robust.

Given that the dependent variable (commuting time) may take value 0 for some workers (i.e., home-based workers), truncated or censored regression models such as the Tobit model (Tobin, 1958) may be preferred (Wooldridge, 2016). However, prior research has compared Tobit models and OLS models when studying time allocations (Frazis and Stewart, 2012; Gershuny, 2012; Foster and Kalenkoski, 2013; Gimenez-Nadal and Molina, 2014, 2016), showing that results using OLS and Tobit models are similar. We have alternatively estimated Tobit models (available upon request), and results are robust to those for OLS models. For the sake of simplicity, we rely on OLS models for the empirical analysis.

We must emphasize that the R-squared statistics shown in all the regressions are below 0.1, with the exceptions of Ireland (0.123) and the Netherlands (0.132). This suggests that, as prior research has concluded, commuting behaviors may be the outcome of a process conditioned by several stochastic and/or non-observable conditions, such as weather, traffic congestion, or communications infrastructure (White, 1986; Rouwendal and Rietveld, 1994; Benito and Oswald, 1999; Van Ommeren et al., 1999; Ross and Zenou, 2008; Van Ommeren and Van der Straaten, 2008; Gimenez-Nadal, Molina and Velilla, 2018a).

\subsection{Results for nordic countries}

Columns (1), (2) and (3) of Table 3 show estimates of Equation (1) for Denmark, Finland, and Sweden, respectively. Estimates show some differences among these countries, as the signs and statistical significance of coefficients associated with explanatory variables vary from one country to the next. Being a male worker is associated with more commuting time in Sweden, while the coefficients are not statistically significant in Denmark and Finland. Age is not significant in Denmark and Finland, while in the case of Sweden, older workers seem to have shorter commutes than their younger counterparts, given that the coefficient is negative and statistically significant at standard levels. Regarding the education level of workers, it does not appear to be correlated with commuting time in Denmark and Sweden, as no statistically significant differences are found among individuals with primary education, secondary education, or university education. However, in Finland, individuals with university education seem to have commuting times similar to individuals with primary education, while workers with only secondary education commute, on average, about $7 \mathrm{~min}$ less than their counterparts.

Living with a married or unmarried partner does not appear to be significantly correlated with commuting in any Nordic country studied, while family size is negatively correlated with commuting time only in Finland, and is not statistically significant in Denmark and Sweden. The number of children under 5 years old is negative and statistically significant in Sweden, but positive and not statistically significant at standard levels in Denmark and Finland. On the other hand, the number of children between 5 and 17 years old is positively correlated with commuting time in Finland, and not statistically significant in Denmark and Sweden. The only variable that seems to have a similar impact on commuting time for all three Nordic countries is that identifying selfemployed workers. On average, the self-employed commute about 25 min less in Denmark, 13 min less in Finland, and 18 min less in Sweden, with these coefficients being statistically significant. This result is consistent with the results of Van Ommeren and Van der Straaten (2008) for Germany, and Gimenez-Nadal, Molina and Velilla (2018a) for the US. Part-time workers also commute shorter distances than their full-time counterparts, but only in Denmark (6 more minutes) and Finland (4 more minutes), as the coefficient for Sweden is small and not statistically significant at standard levels.

Finally, focusing on the nine occupational categories included in the regressions (the tenth category, "armed forces", is taken as reference), estimates show different results for the three Nordic countries. First,
Table 3

Estimates on Nordic and Anglo-Saxon countries.

\begin{tabular}{|c|c|c|c|c|c|}
\hline \multirow[t]{2}{*}{ VARIABLES } & \multirow{2}{*}{$\frac{(1)}{\text { Denmark }}$} & \multirow{2}{*}{$\frac{(2)}{\text { Finland }}$} & \multirow{2}{*}{$\frac{(3)}{\text { Sweden }}$} & \multirow{2}{*}{$\frac{(4)}{\text { Ireland }}$} & \multirow{2}{*}{$\frac{(5)}{\mathrm{UK}}$} \\
\hline & & & & & \\
\hline Gender & $\begin{array}{l}2.265 \\
(1.996)\end{array}$ & $\begin{array}{l}-1.762 \\
(2.182)\end{array}$ & $\begin{array}{l}4.142^{c} \\
(2.363)\end{array}$ & $\begin{array}{l}6.901^{\mathrm{a}} \\
(2.540)\end{array}$ & $\begin{array}{l}4.657^{b} \\
(2.114)\end{array}$ \\
\hline Age & $\begin{array}{l}-0.008 \\
(0.086)\end{array}$ & $\begin{array}{l}0.033 \\
(0.083)\end{array}$ & $\begin{array}{l}-0.181^{\mathrm{c}} \\
(0.101)\end{array}$ & $\begin{array}{l}0.012 \\
(0.112)\end{array}$ & $\begin{array}{l}-0.037 \\
(0.088)\end{array}$ \\
\hline Secondary ed. & $\begin{array}{l}0.896 \\
(3.296)\end{array}$ & $\begin{array}{l}-6.906^{b} \\
(3.477)\end{array}$ & $\begin{array}{l}-1.102 \\
(4.334)\end{array}$ & $\begin{array}{l}-3.429 \\
(3.714)\end{array}$ & $\begin{array}{l}1.414 \\
(2.595)\end{array}$ \\
\hline University ed. & $\begin{array}{l}5.004 \\
(3.663)\end{array}$ & $\begin{array}{l}-3.867 \\
(4.071)\end{array}$ & $\begin{array}{l}6.401 \\
(4.784)\end{array}$ & $\begin{array}{l}-1.763 \\
(4.265)\end{array}$ & $\begin{array}{l}9.109^{\mathrm{a}} \\
(2.580)\end{array}$ \\
\hline Partner & $\begin{array}{l}3.964 \\
(2.587)\end{array}$ & $\begin{array}{l}3.376 \\
(2.834)\end{array}$ & $\begin{array}{l}-4.748 \\
(3.253)\end{array}$ & $\begin{array}{l}3.062 \\
(2.666)\end{array}$ & $\begin{array}{l}-2.112 \\
(2.256)\end{array}$ \\
\hline Family size & $\begin{array}{l}-1.683 \\
(1.314)\end{array}$ & $\begin{array}{l}-4.010^{c} \\
(2.158)\end{array}$ & $\begin{array}{l}2.320 \\
(2.048)\end{array}$ & $\begin{array}{l}1.058 \\
(1.278)\end{array}$ & $\begin{array}{l}-0.462 \\
(1.021)\end{array}$ \\
\hline $\begin{array}{c}\text { N. children } \\
\text { under } 5\end{array}$ & $\begin{array}{l}0.839 \\
(2.091)\end{array}$ & $\begin{array}{l}4.901 \\
(3.187)\end{array}$ & $\begin{array}{l}-5.321^{\mathrm{c}} \\
(3.063)\end{array}$ & $\begin{array}{l}4.750^{\circ} \\
(2.426)\end{array}$ & $\begin{array}{l}0.753 \\
(2.061)\end{array}$ \\
\hline N. children 5-17 & $\begin{array}{l}0.588 \\
(1.544)\end{array}$ & $\begin{array}{l}4.231^{c} \\
(2.523)\end{array}$ & $\begin{array}{l}-3.474 \\
(2.202)\end{array}$ & $\begin{array}{l}0.905 \\
(1.625)\end{array}$ & $\begin{array}{l}0.633 \\
(1.412)\end{array}$ \\
\hline Self employed & $\begin{array}{l}-25.144^{\mathrm{a}} \\
(3.214)\end{array}$ & $\begin{array}{l}-12.894^{a} \\
(3.412)\end{array}$ & $\begin{array}{l}-17.973^{\mathrm{a}} \\
(3.836)\end{array}$ & $\begin{array}{l}-22.762^{\mathrm{a}} \\
(3.324)\end{array}$ & $\begin{array}{l}-12.640^{\mathrm{a}} \\
(3.671)\end{array}$ \\
\hline Full time worker & $\begin{array}{l}6.447^{\mathrm{a}} \\
(2.023)\end{array}$ & $\begin{array}{l}4.142^{b} \\
(2.104)\end{array}$ & $\begin{array}{l}0.452 \\
(2.520)\end{array}$ & $\begin{array}{l}6.619^{a} \\
(2.065)\end{array}$ & $\begin{array}{l}9.628^{\mathrm{a}} \\
(1.927)\end{array}$ \\
\hline \multicolumn{6}{|l|}{ Occupations: } \\
\hline Managers & $\begin{array}{l}-8.407 \\
(9.669)\end{array}$ & $\begin{array}{l}32.067^{\mathrm{a}} \\
(6.087)\end{array}$ & $\begin{array}{l}1.296 \\
(11.864)\end{array}$ & $\begin{array}{l}-5.139 \\
(38.387)\end{array}$ & $\begin{array}{l}54.286^{a} \\
(3.942)\end{array}$ \\
\hline Professionals & $\begin{array}{l}-8.845 \\
(9.300)\end{array}$ & $\begin{array}{l}26.896^{a} \\
(4.998)\end{array}$ & $\begin{array}{l}-6.621 \\
(11.421)\end{array}$ & $\begin{array}{l}-16.125 \\
(38.350)\end{array}$ & $\begin{array}{l}54.585^{a} \\
(4.277)\end{array}$ \\
\hline Technicians & $\begin{array}{l}-10.201 \\
(9.327)\end{array}$ & $\begin{array}{l}29.365^{\mathrm{a}} \\
(5.199)\end{array}$ & $\begin{array}{l}-1.581 \\
(11.791)\end{array}$ & $\begin{array}{l}-8.840 \\
(38.395)\end{array}$ & $\begin{array}{l}56.374^{a} \\
(4.100)\end{array}$ \\
\hline \multirow[t]{2}{*}{$\begin{array}{l}\text { Clerical } \\
\text { support }\end{array}$} & -8.745 & $27.370^{\mathrm{a}}$ & -5.014 & -23.792 & $50.629^{a}$ \\
\hline & (9.803) & (5.807) & (12.196) & $(38.157)$ & (3.655) \\
\hline \multirow[t]{2}{*}{$\begin{array}{l}\text { Service and } \\
\text { sales }\end{array}$} & $-21.207^{\mathrm{b}}$ & $16.155^{\mathrm{a}}$ & -13.374 & -29.321 & $45.128^{a}$ \\
\hline & (9.407) & (5.163) & (11.864) & $(38.096)$ & (3.296) \\
\hline \multirow[t]{2}{*}{$\begin{array}{l}\text { Agriculture/ } \\
\text { forest/fish }\end{array}$} & $-25.911^{b}$ & $15.773^{\mathrm{b}}$ & -12.204 & -37.018 & $36.115^{\mathrm{a}}$ \\
\hline & (11.190) & $(7.622)$ & $(14.298)$ & $(38.230)$ & $(6.648)$ \\
\hline \multirow[t]{2}{*}{$\begin{array}{l}\text { Craft/related } \\
\text { trade }\end{array}$} & $-16.148^{c}$ & $27.975^{\mathrm{a}}$ & -1.386 & -8.743 & $59.382^{\mathrm{a}}$ \\
\hline & $(9.417)$ & (5.453) & $(12.478)$ & $(38.291)$ & $(5.764)$ \\
\hline Operators & $\begin{array}{l}-20.686^{\mathrm{b}} \\
(9.697)\end{array}$ & $\begin{array}{l}20.441^{\mathrm{a}} \\
(5.272)\end{array}$ & $\begin{array}{l}-7.888 \\
(12.165)\end{array}$ & $\begin{array}{l}-27.077 \\
(38.161)\end{array}$ & $\begin{array}{l}40.276^{a} \\
(3.900)\end{array}$ \\
\hline $\begin{array}{l}\text { Elementary } \\
\text { occ. }\end{array}$ & $\begin{array}{l}-17.778^{c} \\
(9.936)\end{array}$ & $\begin{array}{l}21.166^{a} \\
(5.760)\end{array}$ & $\begin{array}{l}-10.938 \\
(12.452)\end{array}$ & $\begin{array}{l}-32.390 \\
(38.081)\end{array}$ & $\begin{array}{l}47.903^{a} \\
(3.956)\end{array}$ \\
\hline Constant & $\begin{array}{l}54.152^{\mathrm{a}} \\
(10.969)\end{array}$ & $\begin{array}{l}26.728^{\mathrm{a}} \\
(7.897)\end{array}$ & $\begin{array}{l}55.757^{\mathrm{a}} \\
(13.365)\end{array}$ & $\begin{array}{l}54.279 \\
(38.584)\end{array}$ & $\begin{array}{l}-10.630^{b} \\
(4.744)\end{array}$ \\
\hline Observations & 1,967 & 1,882 & 1,833 & 1,847 & 2,903 \\
\hline R-squared & 0.077 & 0.047 & 0.037 & 0.123 & 0.059 \\
\hline
\end{tabular}

Note: Robust standard errors in parentheses. The sample (EWCS, 2010-2015) is restricted to employed workers. Commuting time is measured in minutes per day. Coefficients estimated using demographic weighting (Katz and Murphy, 1992; Aguiar and Hurst, 2007; Gimenez-Nadal and Sevilla, 2012), to ensure a constant representation of types of workers (e.g., age cohorts, gender, and full-time status), years, and countries. Reference category for occupation: Armed forces.

\footnotetext{
a Significant at the $99 \%$.

b Significant at the $95 \%$.

c Significant at the $90 \%$.
}

none of the coefficients associated with occupations is statistically significant in the case of Sweden, suggesting that workers in different occupations do not have different commuting behaviors. However, coefficients are highly significant in Denmark and Sweden. Specifically, Danish workers in services and sales; agriculture, forestry and fishery; craft and related trade; operators; and elementary occupations report shorter commuting times than their counterparts in the remaining occupation categories. In the case of Finland, however, all the occupations are positive and highly significant, revealing that workers in armed 
forces have the shortest commuting times among all the occupations. Furthermore, the longest commutes are estimated among managers and technicians, suggesting that working in different occupations may be correlated with different commuting behaviors in both Denmark and Finland.

\subsection{Results for Anglo-Saxon countries}

Columns (5) and (6) of Table 3 show estimates of Equation (1) for Ireland and the United Kingdom, respectively. Estimates show some similar results. For instance, male workers commute about 7 more minutes than their female counterparts, net of observed heterogeneity, in Ireland, while the analogous magnitude for the UK is 5 more minutes, with both coefficients being statistically significant. The remaining socio-demographic coefficients are not statistically significant at standard levels, with the exception of university education in the UK, indicating that workers with university education commute about 9 more minutes than their counterparts. This coefficient is not statistically significant for Ireland. Furthermore, self-employed workers commute about 23 fewer minutes than their employee counterparts in Ireland, and about 13 fewer minutes in the UK. Similarly, full-time workers commute about 7 and 10 more minutes than part-time workers in Ireland and the UK, respectively.

Regarding occupations, coefficients are not statistically significant in Ireland, indicating that different occupations are not associated with heterogeneous commuting behaviors, net of observables. For the UK, taking armed forces as reference, managers, professionals, technicians, clerical support workers, and craft and trade workers commute more than 50 more minutes than their counterparts. In addition, service and sales workers, operators, and elementary occupations commute between 40 and 50 more minutes than their armed forces counterparts; and workers in agriculture, fishery and forestry, about 36 more minutes.

\subsection{Results for mediterranean countries}

Table 4 shows estimates of Equation (1) for Greece, Italy, Portugal and Spain. First, none of the coefficients associated with occupation is statistically significant at standard levels for any of the four. Therefore, commuting times do not appear to differ for workers in different occupations, as is the case for Denmark and Sweden.

In terms of socio-demographics, being male is significantly correlated with commuting time only in Italy, where male workers commute, on average, about 3 more minutes than their female counterparts, net of observed heterogeneity. The coefficient associated with age is not statistically significant, suggesting that commuting behaviors do not depend on the age of workers. However, education seems to be correlated with commuting for all the countries, but differentially. In Greece, Italy, and Spain, individuals with secondary education and individuals with primary education have similar commuting times. However, individuals with university education commute, on average, 9 more minutes in Greece, 7 more minutes in Italy, and 4 more minutes in Spain, relative to other workers. In Portugal, university education is not correlated with commuting, since workers who have attended university have commuting times similar to workers with primary education. However, workers with secondary education commute 5 more minutes than their counterparts.

Household composition does not appear to be significantly correlated with commuting time in any of the Mediterranean countries, as coefficients associated with living with a partner, the number of children, and family size are not statistically significant at standard levels. However, self-employed workers commute shorter distances than employees, with differences of 18, 11, 12, and $13 \mathrm{~min}$ in Greece, Italy, Portugal and Spain, respectively. These differences are all significant. Finally, the full-time status of workers is negative but not statistically significant in Greece and Spain, and positive and statistically significant in Italy and Portugal, where full-time workers commute about 5 more
Table 4

Estimates on Mediterranean countries.

\begin{tabular}{|c|c|c|c|c|}
\hline \multirow[t]{2}{*}{ VARIABLES } & \multirow{2}{*}{$\frac{(1)}{\text { Greece }}$} & \multirow{2}{*}{$\frac{(2)}{\text { Italy }}$} & \multirow{2}{*}{$\frac{(3)}{\text { Portugal }}$} & \multirow{2}{*}{$\frac{\text { (4) }}{\text { Spain }}$} \\
\hline & & & & \\
\hline Gender & $\begin{array}{l}1.997 \\
(1.669)\end{array}$ & $\begin{array}{l}3.252^{b} \\
(1.443)\end{array}$ & $\begin{array}{l}0.333 \\
(1.481)\end{array}$ & $\begin{array}{l}1.052 \\
(1.282)\end{array}$ \\
\hline Age & $\begin{array}{l}0.101 \\
(0.095)\end{array}$ & $\begin{array}{l}0.016 \\
(0.073)\end{array}$ & $\begin{array}{l}-0.066 \\
(0.077)\end{array}$ & $\begin{array}{l}-0.043 \\
(0.061)\end{array}$ \\
\hline Secondary ed. & $\begin{array}{l}2.623 \\
(1.901)\end{array}$ & $\begin{array}{l}0.575 \\
(1.849)\end{array}$ & $\begin{array}{l}4.637^{\mathrm{b}} \\
(1.982)\end{array}$ & $\begin{array}{l}1.011 \\
(1.464)\end{array}$ \\
\hline University ed. & $\begin{array}{l}8.714^{a} \\
(2.585)\end{array}$ & $\begin{array}{l}6.896^{b} \\
(2.969)\end{array}$ & $\begin{array}{l}4.664 \\
(3.009)\end{array}$ & $\begin{array}{l}3.855^{\mathrm{b}} \\
(1.853)\end{array}$ \\
\hline Partner & $\begin{array}{l}0.780 \\
(2.040)\end{array}$ & $\begin{array}{l}-0.133 \\
(1.660)\end{array}$ & $\begin{array}{l}-2.289 \\
(1.650)\end{array}$ & $\begin{array}{l}0.422 \\
(1.265)\end{array}$ \\
\hline Family size & $\begin{array}{l}0.188 \\
(1.044)\end{array}$ & $\begin{array}{l}0.262 \\
(0.707)\end{array}$ & $\begin{array}{l}-0.616 \\
(0.801)\end{array}$ & $\begin{array}{l}-0.062 \\
(0.634)\end{array}$ \\
\hline N. children under 5 & $\begin{array}{l}-1.661 \\
(1.907)\end{array}$ & $\begin{array}{l}-1.472 \\
(2.094)\end{array}$ & $\begin{array}{l}1.524 \\
(1.979)\end{array}$ & $\begin{array}{l}0.367 \\
(1.584)\end{array}$ \\
\hline N. children 5-17 & $\begin{array}{l}-0.897 \\
(1.246)\end{array}$ & $\begin{array}{l}0.506 \\
(1.117)\end{array}$ & $\begin{array}{l}2.135 \\
(1.339)\end{array}$ & $\begin{array}{l}1.055 \\
(0.983)\end{array}$ \\
\hline Self employed & $\begin{array}{l}-17.779^{\mathrm{a}} \\
(2.040)\end{array}$ & $\begin{array}{l}-10.999^{\mathrm{a}} \\
(1.901)\end{array}$ & $\begin{array}{l}-12.284^{\mathrm{a}} \\
(2.709)\end{array}$ & $\begin{array}{l}-12.693^{\mathrm{a}} \\
(1.744)\end{array}$ \\
\hline Full time worker & $\begin{array}{l}-0.581 \\
(2.064)\end{array}$ & $\begin{array}{l}4.869^{a} \\
(1.402)\end{array}$ & $\begin{array}{l}5.090^{\mathrm{b}} \\
(2.008)\end{array}$ & $\begin{array}{l}-0.767 \\
(1.360)\end{array}$ \\
\hline \multicolumn{5}{|l|}{ Occupations: } \\
\hline Managers & $\begin{array}{l}3.019 \\
(9.862)\end{array}$ & $\begin{array}{l}-4.546 \\
(9.510)\end{array}$ & $\begin{array}{l}-5.097 \\
(19.737)\end{array}$ & $\begin{array}{l}-0.953 \\
(4.192)\end{array}$ \\
\hline Professionals & $\begin{array}{l}2.230 \\
(9.647)\end{array}$ & $\begin{array}{l}-5.746 \\
(9.567)\end{array}$ & $\begin{array}{l}-5.957 \\
(19.325)\end{array}$ & $\begin{array}{l}6.459 \\
(3.975)\end{array}$ \\
\hline Technicians & $\begin{array}{l}3.101 \\
(9.906)\end{array}$ & $\begin{array}{l}-2.387 \\
(9.345)\end{array}$ & $\begin{array}{l}-12.076 \\
(19.191)\end{array}$ & $\begin{array}{l}4.231 \\
(3.876)\end{array}$ \\
\hline Clerical support & $\begin{array}{l}-0.506 \\
(9.695)\end{array}$ & $\begin{array}{l}-3.875 \\
(9.392)\end{array}$ & $\begin{array}{l}-10.134 \\
(19.193)\end{array}$ & $\begin{array}{l}2.480 \\
(3.787)\end{array}$ \\
\hline Service and sales & $\begin{array}{l}-4.297 \\
(9.575)\end{array}$ & $\begin{array}{l}-4.933 \\
(9.393)\end{array}$ & $\begin{array}{l}-11.674 \\
(19.168)\end{array}$ & $\begin{array}{l}-2.818 \\
(3.761)\end{array}$ \\
\hline Agriculture/forest/fish & $\begin{array}{l}3.552 \\
(9.844)\end{array}$ & $\begin{array}{l}-5.892 \\
(9.650)\end{array}$ & $\begin{array}{l}-10.983 \\
(19.235)\end{array}$ & $\begin{array}{l}1.886 \\
(5.281)\end{array}$ \\
\hline Craft/related trade & $\begin{array}{l}5.774 \\
(9.770)\end{array}$ & $\begin{array}{l}-3.391 \\
(9.411)\end{array}$ & $\begin{array}{l}-10.715 \\
(19.044)\end{array}$ & $\begin{array}{l}3.384 \\
(3.899)\end{array}$ \\
\hline Operators & $\begin{array}{l}-5.055 \\
(9.665)\end{array}$ & $\begin{array}{l}-7.068 \\
(9.465)\end{array}$ & $\begin{array}{l}-13.921 \\
(19.051)\end{array}$ & $\begin{array}{l}0.205 \\
(4.073)\end{array}$ \\
\hline Elementary occ. & $\begin{array}{l}2.428 \\
(10.002)\end{array}$ & $\begin{array}{l}-8.953 \\
(9.423)\end{array}$ & $\begin{array}{l}-5.798 \\
(19.173)\end{array}$ & $\begin{array}{l}1.342 \\
(3.784)\end{array}$ \\
\hline Constant & $\begin{array}{l}27.862^{\mathrm{a}} \\
(10.406)\end{array}$ & $\begin{array}{l}28.044^{\mathrm{a}} \\
(10.427)\end{array}$ & $\begin{array}{l}35.387^{c} \\
(20.153)\end{array}$ & $\begin{array}{l}34.427^{a} \\
(5.125)\end{array}$ \\
\hline Observations & 1,886 & 2,371 & 1,671 & 4,017 \\
\hline R-squared & 0.099 & 0.044 & 0.061 & 0.040 \\
\hline
\end{tabular}

Note: Robust standard errors in parentheses. The sample (EWCS, 2010-2015) is restricted to employed workers. Commuting time is measured in minutes per day. Coefficients estimated using demographic weighting (Katz and Murphy, 1992; Aguiar and Hurst, 2007; Gimenez-Nadal and Sevilla, 2012), to ensure a constant representation of types of workers (e.g., age cohorts, gender, and full-time status), years, and countries. Reference category for occupation: Armed forces.

\footnotetext{
a Significant at the $99 \%$.

b Significant at the $95 \%$.

c Significant at the $90 \%$.
}

minutes than do part-time workers.

\subsection{Results for continental countries}

Table 5 shows estimates for Austria, Belgium, France, Germany, Luxembourg, and the Netherlands. We observe that being male is positively correlated to commuting time in all the Continental countries, with the exception of Luxembourg. Specifically, net of observed heterogeneity, male workers commute $6,10,5,3$, and 4 more minutes, relative to female workers, in Austria, Belgium, France, Germany, and the Netherlands, respectively. Thus, differences in socio-demographic characteristics between male and female workers in these countries do not explain the gender gap in commuting time.

Regarding age, older workers in Austria and Belgium seem to 
Table 5

Estimates on Continental countries.

\begin{tabular}{|c|c|c|c|c|c|c|}
\hline \multirow[t]{2}{*}{ VARIABLES } & \multirow{2}{*}{$\frac{(1)}{\text { Austria }}$} & \multirow{2}{*}{$\frac{(2)}{\text { Belgium }}$} & \multirow{2}{*}{$\frac{(3)}{\text { France }}$} & \multirow{2}{*}{$\frac{(4)}{\text { Germany }}$} & \multirow{2}{*}{$\frac{(5)}{\text { Luxembourg }}$} & \multirow{2}{*}{$\frac{(6)}{\text { Netherlands }}$} \\
\hline & & & & & & \\
\hline \multirow[t]{2}{*}{ Gender } & $6.376^{\mathrm{a}}$ & $9.720^{\mathrm{a}}$ & $5.078^{\mathrm{a}}$ & $2.648^{c}$ & 1.772 & $4.329^{c}$ \\
\hline & (1.977) & $(1.291)$ & $(1.462)$ & (1.598) & (1.895) & $(2.216)$ \\
\hline \multirow[t]{2}{*}{ Age } & $0.146^{c}$ & $0.121^{\mathrm{b}}$ & $-0.139^{b}$ & 0.070 & 0.044 & 0.082 \\
\hline & $(0.083)$ & $(0.061)$ & $(0.063)$ & $(0.060)$ & $(0.093)$ & $(0.090)$ \\
\hline \multirow[t]{2}{*}{ Secondary ed. } & -2.574 & 0.031 & -2.924 & -0.691 & -0.154 & 0.135 \\
\hline & $(2.721)$ & $(1.707)$ & $(1.824)$ & $(4.200)$ & $(2.459)$ & $(2.475)$ \\
\hline \multirow[t]{2}{*}{ University ed. } & 2.386 & $9.105^{\mathrm{a}}$ & 3.003 & -2.603 & 1.156 & $6.975^{\mathrm{b}}$ \\
\hline & $(4.226)$ & $(1.970)$ & $(2.334)$ & $(4.196)$ & (3.104) & $(3.058)$ \\
\hline \multirow[t]{2}{*}{ Partner } & $3.567^{c}$ & 1.656 & 2.125 & 0.607 & $-4.011^{c}$ & $4.419^{c}$ \\
\hline & $(2.093)$ & $(1.480)$ & (1.635) & $(1.781)$ & $(2.336)$ & $(2.300)$ \\
\hline \multirow[t]{2}{*}{ Family size } & -1.257 & -0.085 & -0.541 & 0.449 & $2.739^{\mathrm{b}}$ & -1.029 \\
\hline & $(0.941)$ & $(0.764)$ & $(0.959)$ & (1.044) & (1.128) & (1.019) \\
\hline \multirow[t]{2}{*}{ N. children under 5} & 2.747 & 1.798 & 1.255 & 1.315 & 3.663 & 3.003 \\
\hline & $(2.436)$ & (1.468) & (1.612) & $(2.226)$ & $(2.477)$ & $(2.418)$ \\
\hline \multirow[t]{2}{*}{ N. children 5-17 } & 1.322 & 0.792 & 0.068 & -1.486 & -1.151 & -0.447 \\
\hline & (1.433) & $(0.951)$ & (1.180) & (1.337) & (1.331) & $(1.266)$ \\
\hline \multirow[t]{2}{*}{ Self employed } & $-24.825^{\mathrm{a}}$ & $-25.236^{a}$ & $-19.031^{\mathrm{a}}$ & $-18.265^{a}$ & $-21.859^{a}$ & $-24.759^{a}$ \\
\hline & $(2.838)$ & $(1.848)$ & $(2.086)$ & $(2.647)$ & $(2.667)$ & $(3.113)$ \\
\hline \multirow[t]{2}{*}{ Full time worker } & $4.513^{\mathrm{b}}$ & $4.032^{\mathrm{a}}$ & $3.749^{\mathrm{b}}$ & $10.197^{\mathrm{a}}$ & 2.719 & $8.490^{\mathrm{a}}$ \\
\hline & $(1.872)$ & (1.253) & (1.465) & (1.588) & $(2.121)$ & $(2.236)$ \\
\hline \multicolumn{7}{|l|}{ Occupations: } \\
\hline \multirow[t]{2}{*}{ Managers } & $-24.391^{b}$ & -11.061 & 2.291 & -9.603 & -2.602 & -51.653 \\
\hline & (11.834) & $(8.132)$ & (8.787) & (9.789) & $(4.506)$ & (35.089) \\
\hline \multirow[t]{2}{*}{ Professionals } & -14.230 & $-14.147^{c}$ & 2.025 & -7.137 & -3.893 & -57.455 \\
\hline & (11.641) & $(8.051)$ & (8.667) & $(9.587)$ & $(3.848)$ & (34.984) \\
\hline \multirow[t]{2}{*}{ Technicians } & -14.023 & -11.681 & -0.822 & -11.310 & -2.103 & -51.654 \\
\hline & (11.733) & $(8.043)$ & $(8.576)$ & (9.393) & (3.983) & (35.020) \\
\hline \multirow[t]{2}{*}{ Clerical support } & -18.135 & -12.766 & 2.692 & -10.367 & 3.414 & -55.757 \\
\hline & (11.493) & (7.987) & (8.599) & $(9.386)$ & $(5.020)$ & (35.009) \\
\hline \multirow[t]{2}{*}{ Service and sales } & $-21.676^{c}$ & $-22.108^{\mathrm{a}}$ & -9.131 & $-16.771^{c}$ & -2.491 & $-66.705^{c}$ \\
\hline & (11.396) & $(7.977)$ & (8.544) & (9.437) & $(4.501)$ & $(34.953)$ \\
\hline Agriculture/forest/fish & $-31.410^{\mathrm{a}}$ & $-33.855^{\mathrm{a}}$ & -14.639 & $-23.207^{b}$ & $-15.345^{c}$ & $-80.121^{b}$ \\
\hline & $(11.817)$ & $(8.762)$ & $(9.095)$ & $(9.762)$ & $(7.838)$ & $(35.009)$ \\
\hline Craft/related trade & $-23.885^{\mathrm{b}}$ & $-17.208^{\mathrm{b}}$ & -2.781 & $-17.030^{c}$ & -5.536 & $-62.190^{c}$ \\
\hline & $(11.551)$ & $(8.058)$ & $(8.651)$ & $(9.340)$ & $(4.484)$ & $(35.064)$ \\
\hline Operators & $-27.763^{\mathrm{b}}$ & $-24.332^{\mathrm{a}}$ & -8.024 & $-19.921^{\mathrm{b}}$ & -2.868 & $-70.009^{\mathrm{b}}$ \\
\hline & $(11.625)$ & $(8.069)$ & $(8.665)$ & $(9.522)$ & (5.409) & $(35.176)$ \\
\hline Elementary occ. & $-29.576^{\mathrm{b}}$ & $-22.953^{\mathrm{a}}$ & -5.558 & $-18.476^{c}$ & -6.970 & $-67.570^{c}$ \\
\hline & $(11.527)$ & $(8.085)$ & $(8.630)$ & $(9.448)$ & $(4.706)$ & $(34.975)$ \\
\hline Constant & $48.228^{\mathrm{a}}$ & $46.245^{\mathrm{a}}$ & $46.132^{\mathrm{a}}$ & $47.977^{\mathrm{a}}$ & $34.591^{\mathrm{a}}$ & $94.833^{\mathrm{a}}$ \\
\hline & $(12.211)$ & $(8.642)$ & $(9.352)$ & (10.908) & $(6.273)$ & $(35.515)$ \\
\hline Observations & 1,836 & 5,946 & 4,192 & 3,780 & 1,825 & 1,902 \\
\hline R-squared & 0.108 & 0.093 & 0.059 & 0.050 & 0.066 & 0.132 \\
\hline
\end{tabular}

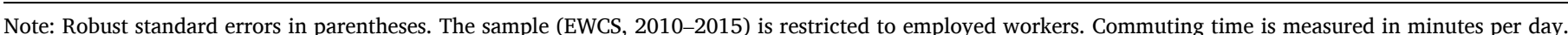

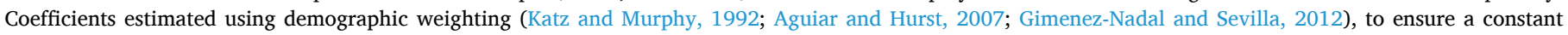
representation of types of workers (e.g., age cohorts, gender, and full-time status), years, and countries. Reference category for occupation: Armed forces.

a Significant at the $99 \%$.

b Significant at the $95 \%$.

c Significant at the $90 \%$.

commute longer distances than younger workers, as one more year of age is associated with about 0.1 more minutes commuting. However, the coefficient for age is negative and statistically significant at standard levels in France, suggesting that younger workers have longer commutes. In terms of education, workers with primary and secondary education levels seem to commute similar distances, as the coefficient for secondary education is not statistically significant in all countries. University educated workers commute about 9 more minutes and 7 more minutes than their counterparts in Belgium and the Netherlands, respectively, with these coefficients being statistically significant, while no differences are found in the rest of the countries.

In terms of household composition, none of the coefficients are statistically significant in France and Germany, suggesting that living with a partner, the number of children, and household size are not associated with commuting behaviors. However, workers who cohabit with a married or unmarried spouse commute about 4 more minutes than do singles in Austria and the Netherlands, but 4 fewer minutes in
Luxembourg. Household size is only significantly correlated with commuting time in Luxembourg, where the associated coefficient is positive and statistically significant at standard levels. The number of children, on the other hand, does not appear to be correlated to commuting in a statistically significant way for any of the countries.

Regarding the labor attributes of workers, self-employed workers report shorter commutes than their employee counterparts in all the countries, as relative to employees they commute 25 fewer minutes in Austria, Belgium and the Netherlands, 19 fewer minutes in France, 18 fewer minutes in Germany, and 22 fewer minutes in Luxembourg. The coefficient associated with being a full-time worker is positive for all the countries, but not statistically significant in the case of Luxembourg, suggesting that, in general, full-time workers commute for longer times than their part-time counterparts.

Finally, in terms of occupation, no coefficients are statistically significant in the case of France, suggesting that commuting times are not influenced by working in different occupations in this country. 
Similarly, the only statistically significant coefficient in Luxembourg is that associated with agriculture, forestry and fishery, suggesting that workers in this occupation commute about 15 fewer minutes, on average, than their counterparts. The remaining coefficients are not statistically significant at standard levels in Luxembourg.

In Austria, all the coefficients are negative, and the longest commutes are those of workers in the armed forces. However, they are statistically significant at standard levels only in the case of managers, services and sales, agriculture, forestry and fishery, craft and related trade, operators, and elementary occupations, who commute between 22 and 31 fewer minutes than their counterparts. Belgium shows similar trends, as all the coefficients associated with occupation are negative, relative to the armed forces. However, they are statistically significant among professionals, services and sales, agriculture, forestry and fishery, craft and related trade, operators, and elementary occupations; and the variation is greater than in Austria, between 14 and 34 fewer minutes than their counterparts. Germany shows, again, similar results, as workers in services and sales, agriculture, forestry and fishery, craft and related trade, operators, and elementary occupations commute between 17 and 23 fewer minutes than do their counterparts. Finally, for the Netherlands, coefficients show the largest commuting differences in terms of occupations. Specifically, workers in services and sales, agriculture, fishery and forestry, craft and related trade, operators, and elementary occupations commute $67,80,62,70$ and 68 fewer minutes, respectively.

\section{The influence of country characteristics}

In this Section we aim to analyze how factors such as urban structure and geographic characteristics, public transport services, transport infrastructure, transport policies or housing costs are related to the time devoted to commuting in the analyzed countries. To that end, we estimate Equation (1) for the pool of the countries, and we include 11 national indices, defined at the country-year level. Specifically, we include 1) the modal split of passenger transport by train, 2) the modal split of passenger transport by car, 3) Road transport fatalities, 4) motorization rates, 5) GDP per capita, 6) unemployment rates, 7) house price indices, 8 ) the share of population in urban areas, 9) the total length of motorways, 10) CEO2 emissions per km from new passenger cars, and 11) the share of buses in total passenger transport (the share of trains is excluded as it is linearly dependent). The source, definition, and average value of the national indices are shown in Table A6 in the Appendix. ${ }^{12}$ These indices aim to measure transport infrastructures and services, and transport policies, at the country level. Additionally, housing prices, per capita GDP, urban characteristics, and the shares of car ownership and public transport have been found to have an impact on commuting times (Naess, 2003, 2006, 2009; Santos et al., 2013; Gimenez-Nadal, Molina and Velilla, 2018a; Mitra and Saphores, 2019). Estimated coefficients for these variables capture differences in commuting time due to differences by year and country in these factors.

Table 6 shows the results of estimating Equation (1) when we pool all the countries and years, controlling for socio-demographic characteristics, occupation, and country fixed effects, and also including the national indices. Estimates show that the higher the share of passengers by train and car, the shorter the average commuting time of countries, although only the coefficient associated with the car index provides statistically significant results at standard levels. Road fatalities are also negatively correlated with commuting times, and so is the length of motorways. Motorization rates (i.e., more vehicles per inhabitant) are correlated with longer commuting times. On the other hand, both GDP per capita and unemployment rates are negatively correlated with

\footnotetext{
12 The EWCS does not include information about transport services and infrastructures at the micro-level, and we thus rely on indicators defined at the country level.
}

Table 6

Pooled estimates.

\begin{tabular}{|c|c|}
\hline \multirow[t]{2}{*}{ VARIABLES } & \multirow{2}{*}{$\frac{(2)}{\text { Plus indices }}$} \\
\hline & \\
\hline Sociodemographics & Yes \\
\hline Occupations & Yes \\
\hline Country F.E. (reference: Netherlands) & Yes \\
\hline \multicolumn{2}{|l|}{ National indices: } \\
\hline Modal split of passenger transport: Train & $\begin{array}{l}-1.608 \\
(1.947)\end{array}$ \\
\hline Modal split of passenger transport: Car & $\begin{array}{l}-2.346^{\mathrm{b}} \\
(0.903)\end{array}$ \\
\hline Road transport fatalities & $\begin{array}{l}-3.760^{c} \\
(1.827)\end{array}$ \\
\hline Motorization rate & $\begin{array}{l}0.108^{b} \\
(0.041)\end{array}$ \\
\hline GDP per capita (PPS) & $\begin{array}{l}-1.124^{\mathrm{a}} \\
(0.308)\end{array}$ \\
\hline Unemployment share & $\begin{array}{l}-2.119^{a} \\
(0.527)\end{array}$ \\
\hline House price index & $\begin{array}{l}0.154 \\
(0.136)\end{array}$ \\
\hline Urban population share & $\begin{array}{l}-1.143 \\
(0.818)\end{array}$ \\
\hline Total length of motorways & $\begin{array}{l}-0.005^{\mathrm{b}} \\
(0.002)\end{array}$ \\
\hline $\mathrm{CO} 2$ emissions per $\mathrm{km}$ from new passenger cars & $\begin{array}{l}0.006 \\
(0.147)\end{array}$ \\
\hline Share of buses in total passenger transport & $\begin{array}{l}0.489 \\
(1.719)\end{array}$ \\
\hline Constant & $\begin{array}{l}384.649^{b} \\
(137.506)\end{array}$ \\
\hline Observations & 39,858 \\
\hline R-squared & 0.071 \\
\hline
\end{tabular}

Note: Robust standard errors in parentheses. The sample (EWCS, 2010-2015) is restricted to employed workers. Commuting time is measured in minutes per day. Coefficients estimated using demographic weighting (Katz and Murphy, 1992; Aguiar and Hurst, 2007; Gimenez-Nadal and Sevilla, 2012), to ensure a constant representation of types of workers (e.g., age cohorts, gender, and full-time status), years, and countries.

a Significant at the $99 \%$.

b Significant at the $95 \%$.

c Significant at the $90 \%$.

commuting times. The house price index, the share of individuals in urban areas, the emissions from new cars, and the share of buses in total passenger transport are all found to be not correlated to commuting times in a statistically significant way. These estimated coefficients suggest that commutes by train and private vehicle are, in general terms, faster than commutes by bus and/or walking. Transport infrastructures and car ownership seem to play significant roles in determining commuting time as, for instance, higher speed limits, worse road transport infrastructures, or more cars per inhabitant may increase commuting times of workers. ${ }^{13}$

\section{Future research on commuting}

Commuting is an activity that workers are involved in daily, with a wide set of implications, not only for workers, but also for employers and for society as a whole. Despite its importance, little effort has been devoted to the analysis of its evolution over time, and thus the analysis

\footnotetext{
13 Comparing the results shown in Table 6, with estimates excluding the national indices, the inclusion of these indices does not help to increase the accuracy of the model (i.e., the R-Squared goes from 0.069 to 0.071 ). Thus, this comparison confirms the conclusions of prior applied research on commuting time, as commutes seem to be a process strongly dependent on stochastic or non-observable factors (van Ommeren and van der Straaten, 2008; Gimenez-Nadal et al., 2020).
} 
of the evolution of commuting time/distance in national contexts presents an important line of future research. ${ }^{14}$ Within this line of research, the evolution of gender gaps in commuting is an important topic, as existing research has analyzed gender issues related to commuting time (see Gimenez-Nadal and Molina, 2016, for a review) but, to the best of our knowledge, the evolution of such gendered issues has received lesser attention. In this context, the use of harmonized datasets, such as time use surveys, where information on the time devoted to commuting can be found for several countries and decades, represents a promising line of research, especially given that time use data has become in recent years a common approach to analyze worker daily behaviors (Aguiar and Hurst, 2007; Ramey and Ramey, 2010; Gimenez-Nadal and Sevilla, 2012; Harms et al., 2019). ${ }^{15}$

Prior research has analyzed the determinants and consequences of commuting time, but there is still no consensus about several aspects of commuting time that require further investigation. For example, despite that some authors have found a significant correlation between earnings and commutes (Leigh, 1986; Timothy and Wheaton, 2001; Ross and Zenou, 2008; Ruppert et al., 2009; Gimenez-Nadal et al., 2018b; French et al., 2020), whether there is a causal link between these two dimensions is a state-of-the-art question in the literature, with little empirical evidence on the link (Mulalic et al., 2014). Similarly, the causal effect of commuting on labor supply and productivity is a topic of high interest that requires further research (Carta and De Philippis, 2018; Grinza and Rycx, 2020). Furthermore, despite having reached a consensus about the negative effects of commuting on worker health, stress, and well-being, existing research has documented spill-over effects to other dimensions of worker activities, such as distorted time use allocations, increased work-family imbalances, or lower experienced utility associated with non-commuting activities (Christian, 2012; Hilbrecht et al., 2014; Kroesen, 2014; Wheatley, 2014; Denstadli et al., 2017; Gimenez- Nadal, Molina and Velilla; 2018b; Gimenez-Nadal and Molina, 2019; Chatterjee et al., 2020). This is a novel area of research that should be further investigated, either searching for different negative spill-over effects of commuting, or analyzing them across subgroups of populations, across countries, and over time.

Another relationship that has been studied is that between commuting time and the type of employment, with prior research reporting commuting differences between employees and self-employed workers in the US and European countries (Van Ommeren and Van der Straaten, 2008; Gimenez-Nadal, Molina and Velilla, 2018a; 2020; Albert et al., 2019), and among occupations (Hanson and Johnston, 1985; Gordon et al., 1989). However, so far this research has documented conditional correlations only. The question of whether longer commutes produce a greater preference for self-employment, or for particular occupations, or oppositely, working as self-employed, or in certain occupation, giving workers the possibility of shorter commutes, is an uninvestigated topic that requires further analysis.

Finally, several authors have reported significant associations

\footnotetext{
${ }^{14}$ For instance, other authors have reported increases in commuting times in recent years in Germany, the Netherlands, and the US, consistent with the results in this paper (Susilo and Maat, 2007; Kirby and LeSage, 2009; McKenzie and Rapino, 2009; Gimenez-Nadal and Molina, 2014).

15 An example of a harmonized dataset containing information based on time use survey is the Multinational Time Use Study (https://www.timeuse. org/mtus), which has been previously used to report over time/cross-country comparisons of other uses of time such as leisure, market work, and housework time (Giménez-Nadal and Sevilla, 2012). Another option would be the use of National Travel Surveys (NTS) to do such over time/cross-country comparisons, although Ahern et al. (2013) state that the comparability might be limited or even impossible due to the application of distinct methodological approaches based on varying concepts (e.g. the definition of what is regarded as a trip), differing data collection times (e.g. workday coverage vs. 7 day week), specific national conditions (e.g. availability of sampling frames etc.) or the prevailing law (e. g. data protection regulations, privacy policy).
}

between commuting time and urban forms, land use, commuting modes, and the availability of public transport services. However, the relationship between commutes and urban characteristics is complex, and may depend on non-observable factors; so there is no consensus about the particular factors at the urban/metropolitan level that affect commuting times (Manning, 2003; Rodríguez, 2004; Van Acker and Witlox, 2011; Gimenez-Nadal et al., 2018a). In this context, this paper shows that some national indices capturing transport infrastructures and services, policies, housing and urban characteristics, or car ownership rates are statistically correlated to commuting time. Further research should use detailed data at the urban and regional level to study what drives increasing commuting times, including information at the microeconomic level, to study what are the precise factors that drive the association between commuting time and urban characteristics, and the quantitative impact of such factors on worker daily commuting trips.

\section{Conclusions}

This paper addresses the evolution of commuting time during the 1990s, 2000s, and 2010s in Austria, Belgium, Denmark, Finland, Germany, Greece, France, Ireland, Italy, Luxembourg, the Netherlands, Portugal, Spain, Sweden, and the United Kingdom, using data from the EWCS. Our results suggest that commuting time has increased during the last three decades in Denmark, Finland, Sweden, Ireland, Italy, Spain, Belgium, France, and the Netherlands, and we find decreasing trends in commuting time in Austria, Germany, Greece and Portugal. Our analysis represents the first empirical study of the evolution of commuting trends in fifteen European countries, using a harmonized source of data.

We also analyze, following prior research, the existence of a gender gap in commuting, where male workers commute more (in time or distance) than do female workers. Our results indicate that, in general, this gap exists in Anglo-Saxon and Continental economies, while it is not found in Nordic and Mediterranean countries. When we consider gender differences in the socio-demographic and labor market characteristics of workers, such gaps in commuting time do not disappear, indicating that the difference in commuting time is not motivated by differences in socio-demographic characteristics and jobs. We also find that country characteristics are relevant.

We analyze the predictors of commuting time during the 2010s, finding that there is some level of heterogeneity in the countries analyzed. For instance, the impact of socio-demographics and household composition vary from one country to another, but in general terms results suggest that part-time workers and self-employed workers have shorter commutes than do their counterparts (Van Ommeren and Van der Straaten, 2008; 2020). Occupation also has a varying impact on commutes, as only in certain countries do different occupations lead to different commuting behaviors, which only partially coincides with prior research (e.g., Hanson and Johnston, 1985; Gordon et al., 1989). We also find that country characteristics are important in the time devoted to commuting by workers, as better road infrastructures seem to reduce commuting times, the generalized use of the car as means of transport (higher motorization rates) is related to longer average commuting, and unemployment rates and GDP, also seem related to commuting times.

The study of commuting time is important for planners and policy makers, and the results of this study may help planners to understand the determinants of commuting times in the countries studied and, therefore, improve the efficiency of future policies. To the extent that commuting time has decreased in Portugal and Germany, it would be interesting to analyze how and why commuting times this has happened (better transport infrastructure, different urban structure, lower moving costs, better information about labor and housing markets ...), which is left for future research. Our results also reveal a significant (and increasing) gender gap in commuting time in certain countries, and the analysis of the specific characteristics of these countries proves 
important for its reduction. Furthermore, given that there is a wide range of heterogeneity among the potential factors that predict commuting time, politicians, policy makers, and transportation planners should consider that the same plans may not operate equally for every economy, and specific measures may be required for each country, although some factors at the country level may have similar effects in all the countries.

Our analysis has certain limitations. First, the first waves of the EWCS include a limited set of variables and, as a consequence, we could not replicate the study of the determinants of commuting time for the entire three decades. Second, as the data is a cross-section, the analysis is based on conditional correlations, and no causal links can be estimated. Finally, estimates reveal low accuracy, and commuting times seem to be determined by a strong stochastic and/or non-observable component.

\section{Author statement}

Conceptualization: J.I. Giménez-Nadal, J.A. Molina, J. Velilla. Data curation: J. Velilla.

Formal analysis: J.I. Giménez-Nadal, J. Velilla.

Funding acquisition: J.I. Giménez-Nadal.

Investigation: J.I. Giménez-Nadal, J. Velilla.

Methodology: J.I. Giménez-Nadal, J. Velilla.
Project administration: J.I. Giménez-Nadal.

Resources: J.I. Giménez-Nadal.

Software: J.I. Giménez-Nadal, J. Velilla.

Supervision: J.I. Giménez-Nadal, J.A. Molina.

Validation: J.I. Giménez-Nadal, J. Velilla.

Visualization: J.I. Giménez-Nadal, J. Velilla.

Writing - original draft: J.I. Giménez-Nadal, J.A. Molina, J. Velilla. Velilla.

Writing - review and editing: J.I. Giménez-Nadal, J.A. Molina, J.

\section{Declaration of competing interest}

None.

\section{Acknowledgement}

This paper has benefitted from funding from the Government of Aragón (Project S32_20R, funded by Program FSE Aragón 2014-2020) and the Spanish Ministry of Science and Innovation (Project PID2019108348RA-I00, funded by MCIN/AEI/10.13039/501100011033). J. Velilla gratefully acknowledges funding from the Government of Aragón Doctoral Grants (Program FSE Aragón 2014-2020).

\section{Appendix A. Additional tables and figures}

\section{Table A1}

Sample sizes, by country and year

\begin{tabular}{|c|c|c|c|c|c|c|}
\hline YEAR & 1995 & 2000 & 2005 & 2010 & 2015 & Total \\
\hline \multicolumn{7}{|l|}{ COUNTRY } \\
\hline Austria & 974 & 1,431 & 869 & 891 & 945 & 5,110 \\
\hline Belgium & 832 & 1,399 & 872 & 3,572 & 2,374 & 9,049 \\
\hline Denmark & 880 & 1,444 & 930 & 1,033 & 934 & 5,221 \\
\hline Finland & 953 & 1,306 & 994 & 958 & 924 & 5,135 \\
\hline France & 886 & 1,422 & 898 & 2,733 & 1,459 & 7,398 \\
\hline Germany & 1,960 & 1,439 & 925 & 1,942 & 1,838 & 8,104 \\
\hline Greece & 941 & 1,415 & 907 & 955 & 931 & 5,149 \\
\hline Ireland & 831 & 1,379 & 895 & 927 & 920 & 4,952 \\
\hline Italy & 906 & 1,461 & 859 & 1,258 & 1,113 & 5,597 \\
\hline Luxembourg & 436 & 474 & 540 & 866 & 959 & 3,275 \\
\hline Netherlands & 961 & 1,403 & 973 & 963 & 939 & 5,239 \\
\hline Portugal & 912 & 1,402 & 916 & 874 & 797 & 4,901 \\
\hline Spain & 884 & 1,426 & 916 & 960 & 3,057 & 7,243 \\
\hline Sweden & 994 & 1,483 & 1,004 & 893 & 940 & 5,314 \\
\hline United Kingdom & 947 & 1,420 & 912 & 1,409 & 1,494 & 6,182 \\
\hline Total & 14,297 & 20,304 & 13,410 & 20,234 & 19,624 & 87,869 \\
\hline
\end{tabular}

Note: The sample (EWCS) is restricted to employed workers in countries with information for the period 1995-2015.

Table A2

Commuting time in the EWCS questionnaire

\begin{tabular}{|c|c|c|c|}
\hline Year & Question \# & Label & Codes \\
\hline 2015 & Q36 & In total, how many minutes per day do you usually spend travelling from home to work and back? & Number minutes per day \\
\hline 2010 & Q31 & In total, how many minutes per day do you usually spend travelling from home to work and back? & Number minutes per day \\
\hline 2005 & Q13 & In total, how many minutes per day do you normally spend travelling from home to work and back? & Number minutes per day \\
\hline 2001 & Q12 & In total, how many minutes per day do you normally spend travelling from home to work and back? & Number minutes per day \\
\hline 2000 & Q15 & In total, how many minutes per day do you normally spend travelling from home to work and back? & Number minutes per day \\
\hline 1995 & Q13 & How many minutes per day do you normally spend travelling from home to work and back in total? & Number minutes per day \\
\hline 1991 & - & - & - \\
\hline
\end{tabular}

Source: EWCS questionnaire concordance grid 1991-2015, historical overview, Eurofound. 
Table A3

Social welfare regimes

\begin{tabular}{ll}
\hline COUNTRY & WELFARE REGIME \\
\hline Austria & Conservative/Corporatist \\
Belgium & Conservative/Corporatist \\
Denmark & Social democratic/Nordic \\
Finland & Social democratic/Nordic \\
France & Conservative/Corporatist \\
Germany & Conservative/Corporatist \\
Greece & Conservative/Corporatist \\
Ireland & Liberal/Anglo-Saxon \\
Italy & Conservative/Corporatist \\
Luxembourg & Conservative/Corporatist \\
Netherlands & Conservative/Corporatist \\
Portugal & Conservative/Corporatist \\
Spain & Conservative/Corporatist \\
Sweden & Social democratic/Nordic \\
United Kingdom & Liberal/Anglo-Saxon \\
\hline
\end{tabular}

Note: "Welfare State" refers to "the set of interventions organized by the state that are aimed at guaranteeing the provision of a minimum level of services to the population via a system of social protection". Source: http://www.lear neurope.eu/files/6713/7526/7222/Welfare_State_models_

in_Europe_en.jpg.

Table A4

Averages of variables

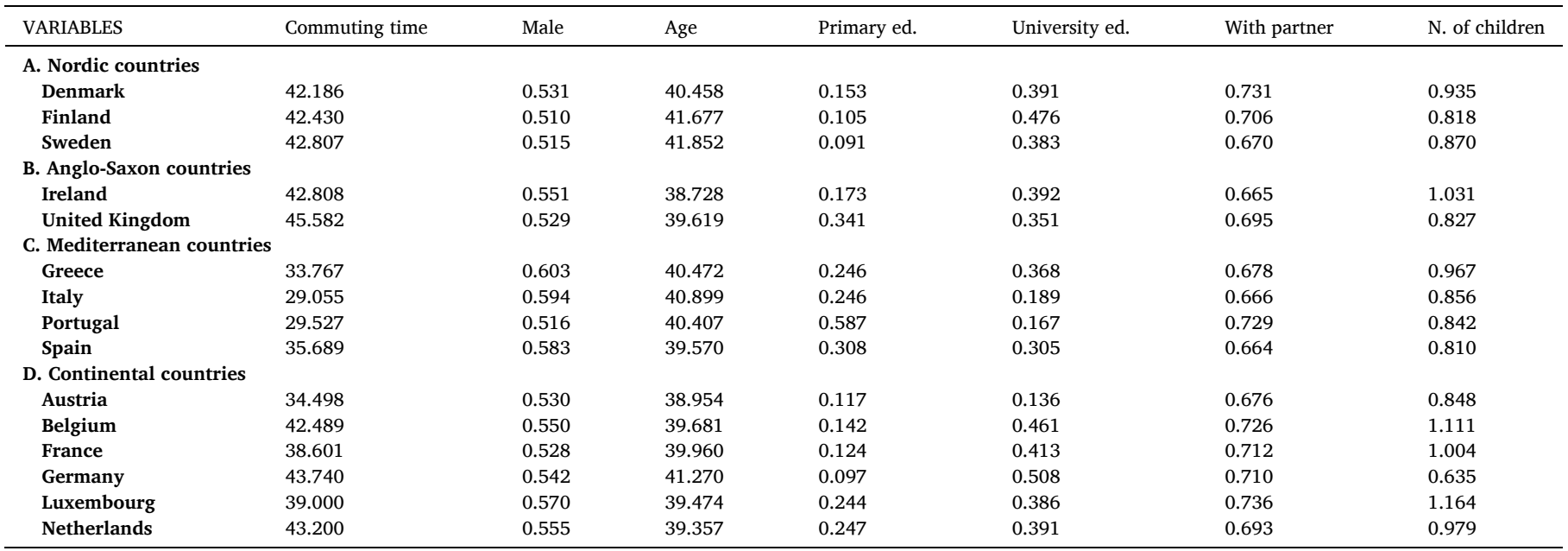

Note: The sample (EWCS 2015) is restricted to employed workers. Averages are computed using sample weights. Commuting time is measured in minutes per day. Male takes value 1 for men, 0 for women. Age is measured in years. Primary education takes value 1 for individuals whose maximum level of education is "pre-primary education", "primary education", or "first stage of basic education"; 0 otherwise. University education takes value 1 for individuals whose maximum level of education is "first stage of university education", or "second stage of university education"; 0 otherwise. With partner takes value 1 for individuals who cohabit with a married or unmarried partner, 0 for singles. Urban area takes value 1 for individuals who reside in urban areas, classified by the Eurostat in terms of NUTS 3 regions, 0 otherwise. Information for education and for the presence of partner and children is available for 2005, 2010 and 2015. Information for living in urban areas is available only for 2015.

Table A5

Zero commuters, by country

\begin{tabular}{lcc}
\hline COUNTRIES & Number of zero commuters & \% of zero commuters \\
\hline $\begin{array}{l}\text { A. Nordic countries } \\
\text { Denmark }\end{array}$ & 191 & 3.658 \\
$\quad$ Finland & 183 & 3.564 \\
$\quad$ Sweden & 138 & 2.597 \\
B. Anglo-Saxon countries & & \\
$\quad$ Ireland & 331 & 6.684 \\
$\quad$ United Kingdom & 323 & 5.225 \\
C. Mediterranean countries & & \\
$\quad$ Greece & 189 & 3.671 \\
$\quad$ Italy & 262 & 4.681 \\
$\quad$ Portugal & 193 & 3.938 \\
$\quad$ Spain & 371 & 5.122
\end{tabular}

(continued on next page) 
Table A5 (continued)

\begin{tabular}{lll}
\hline COUNTRIES & Number of zero commuters & \% of zero commuters \\
\hline D. Continental countries & & \\
Austria & 335 & 6.556 \\
Belgium & 521 & 5.758 \\
France & 572 & 7.732 \\
Germany & 257 & 3.171 \\
Luxembourg & 137 & 4.183 \\
Netherlands & 244 & 4.657 \\
\hline
\end{tabular}

Note: The sample (EWCS, 1995-2015) is restricted to employed workers.

Table A6

Variables defined at the country level

\begin{tabular}{|c|c|}
\hline INDICES & DEFINITION \\
\hline $\begin{array}{l}\text { Modal split of passenger transport: } \\
\text { Train }\end{array}$ & $\begin{array}{l}\text { "This indicator is defined as the percentage share of each mode of transport in total inland transport, expressed in passenger-kilometres } \\
\text { (pkm). It is based on transport by passenger trains." }\end{array}$ \\
\hline Modal split of passenger transport: Car & $\begin{array}{l}\text { "This indicator is defined as the percentage share of each mode of transport in total inland transport, expressed in passenger-kilometres } \\
\text { (pkm). It is based on transport by passenger cars." }\end{array}$ \\
\hline Road transport fatalities & "Road transport road traffic fatalities. Deaths per 100,000 inhabitants." \\
\hline Motorization rate & "Passenger cars per 1000 inhabitants" \\
\hline GDP per capita (PPS) & "Gross domestic product at market prices. Current prices, purchasing power standard (PPS, EU27 from 2020) per capita" \\
\hline Unemployment share & "Unemployment, percentage of active population." \\
\hline House price index & $\begin{array}{l}\text { "Price changes of all residential properties purchased by households (flats, detached houses, terraced houses, etc.), both new and existing, } \\
\text { independently of their final use and their previous owners. Only market prices are considered, self-build dwellings are therefore excluded. } \\
\text { The land component is included. The data are expressed as annual average index } 2015=100 \text {, as } 3 \text { years } \% \text { change and annual average } \\
\text { rate of change." }\end{array}$ \\
\hline Urban population share & $\begin{array}{l}\text { "Urban population (\% of total population). Urban population refers to people living in urban areas as defined by national statistical } \\
\text { offices." }\end{array}$ \\
\hline Total length of motorways & "Total length of motorways (kilometers)." \\
\hline $\begin{array}{l}\text { CO2 emissions per km from new } \\
\text { passenger cars }\end{array}$ & "Average carbon dioxide ( $\mathrm{CO} 2)$ emissions per km by new passenger cars in a given year." \\
\hline $\begin{array}{l}\text { Share of buses in total passenger } \\
\text { transport }\end{array}$ & $\begin{array}{l}\text { "Share of collective transport modes in total inland passenger transport performance, expressed in passenger-kilometres (pkm). Collective } \\
\text { transport modes refer to buses, including coaches and trolley-buses." }\end{array}$ \\
\hline
\end{tabular}

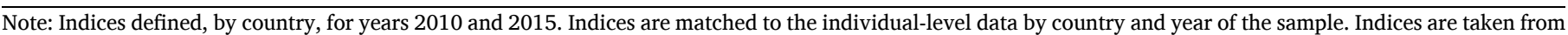

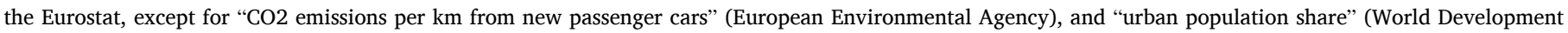
Indicators).

\section{Appendix B. Demographic weighting}

We report trends in commuting time over the last three decades holding constant the demographic composition of the sample, following Aguiar and Hurst (2007) and Gimenez-Nadal and Sevilla (2012). Specifically, we divide the sample into demographic cells defined by five age cohorts (16-25 years, 26-35 years, 36-45 years, 46-55 years, and 56-65 years, all inclusive), two gender categories (male and female), and whether or not workers are full-time or part-time workers. We do not create separate cells distinguishing education categories or household composition (e.g., the presence of children), due to the availability of such information in the EWCS data. This division yields twenty demographic cells for each country. To calculate the constant weights used for our demographic adjustments, we pool together all the waves of the EWCS data for each country, and compute the percentage of the population that resides in each demographic cell for each country. Following Katz and Murphy (1992), we use these fixed weights to calculate weighted means for commuting time in each year.

We follow Gimenez-Nadal and Sevilla (2012) in calculating means for each subsample, and scale weights to sum exactly one. When pooling the different countries in the EWCS data together to compute the percentage of the population in each of our cells, we used the sample weights provided by the EWCS to ensure the data is representative of the total population. We adjusted these weights so that each population cell is equally represented in the overall sample.

\section{References}

Aguiar, M., Hurst, E., 2007. Measuring trends in leisure: the allocation of time over five decades. Q. J. Econ. 122 (3), 969-1006.

Ahern, A., Weyman, G., Redelbach, M., Schulz, A., Akkermands, L., Vannacci, L., Anoyrkati, E., van Grinsven, A., 2013. Analysis of National Travel Statistics in Europe. JRC Technical Reports. Report EUR 26054 EN.

Albert, J.F., Casado-Díaz, J.M., Simón, H., 2019. The commuting behaviour of selfemployed workers: evidence for Spain. Pap. Reg. Sci. 98 (6), 2455-2477.

Allen, S.G., 1983. How much does absenteeism cost? J. Hum. Resour. 18 (3), 379-393.

Benito, A., Oswald, A.J., 1999. Commuting in Great Britain in the 1990s. University of Warwick.

Bonke, J., 2005. Paid work and unpaid work: diary information versus questionnaire information. Soc. Indicat. Res. 70 (3), 349-368.

Carta, F., De Philippis, M., 2018. You've come a long way, baby. Husbands' commuting time and family labour supply. Reg. Sci. Urban Econ. 69, 25-37.

Chatterjee, K., Chng, S., Clark, B., Davis, A., De Vos, J., Ettema, D., Reardon, L., 2020. Commuting and wellbeing: a critical overview of the literature with implications for policy and future research. Transport Rev. 40 (1), 5-34.
Christian, T.J., 2012. Automobile commuting duration and the quantity of time spent with spouse, children, and friends. Prev. Med. 55 (3), 215-218.

Crane, R., 2007. Is there a quiet revolution in women's travel? Revisiting the gender gap in commuting. J. Am. Plann. Assoc. 73 (3), 298-316.

Cropper, M.L., Gordon, P.L., 1991. Wasteful commuting: a re-examination. J. Urban Econ. 29 (1), 2-13.

Dargay, J.M., Clark, S., 2012. The determinants of long distance travel in Great Britain. Transport. Res. Pol. Pract. 46 (3), 576-587.

Deding, M., Filges, T., Van Ommeren, J., 2009. Spatial mobility and commuting: the case of two-earner households. J. Reg. Sci. 49 (1), 113-147.

Denstadli, J.M., Julsrud, T.E., Christiansen, P., 2017. Urban commuting-A threat to the work-family balance? J. Transport Geogr. 61, 87-94.

Dex, S., Clark, A., Taylor, M., 1995. Household Labour Supply. Research Series No. 43. Employment Department, Sheffield.

Dickerson, A., Hole, A.R., Munford, L.A., 2014. The relationship between well-being and commuting revisited: does the choice of methodology matter? Reg. Sci. Urban Econ. 49, 321-329.

Doyle, D., Taylor, B., 2000. Variation in metropolitan travel behaviour by sex and ethnicity. In: Travel Patterns of People of Color: Final Report. U.S. Department of 
Transportation, Federal Highway Administration, Columbus, Ohio. Washington, DC, pp. 181-244 prepared by Battelle.

Foster, G., Kalenkoski, C.M., 2013. Tobit or OLS? An empirical evaluation under different diary window lengths. Appl. Econ. 45 (20), 2994-3010.

Frazis, H., Stewart, J., 2012. How to think about time-use data: what inferences can we make about long-and short-run time use from time diaries? Ann. Econ. Stat. 105/ 106, 231-245.

French, M.T., Popovici, I., Timming, A.R., 2020. Analysing the effect of commuting time on earnings among young adults. Appl. Econ. 1-16.

Frey, B.S., Stutzer, A., 2008. Stress that doesn't pay: the commuting paradox. Scand. J. Econ. 110, 339-366.

Gershuny, J., 2012. Too many zeros: a method for estimating long-term time-use from short diaries. Ann. Econ. Stat. 105/106, 247-270.

Gimenez-Nadal, J.I., Molina, J.A., 2014. Commuting time and labour supply in The Netherlands: a time use study. J. Transport Econ. Pol. 48 (3), 409-426.

Gimenez-Nadal, J.I., Molina, J.A., 2016. Commuting time and household responsibilities: evidence using propensity score matching. J. Reg. Sci. 56 (2), 332-359.

Gimenez-Nadal, J.I., Molina, J.A., 2019. Daily feelings of US workers and commuting time. J. Transport Health 12, 21-33.

Gimenez-Nadal, J.I., Sevilla, A., 2012. Trends in time allocation: a cross-country analysis Eur. Econ. Rev. 56 (6), 1338-1359.

Gimenez-Nadal, J.I., Molina, J.A., Velilla, J., 2018a. The commuting behavior of workers in the United States: differences between the employed and the self-employed. J. Transport Geogr. 66 (1), 19-29.

Gimenez-Nadal, J.I., Molina, J.A., Velilla, J., 2019. Work time and well-being for workers at home: evidence from the American time use survey. Int. J. Manpow. 41 (2), $184-206$

Gimenez-Nadal, J.I., Molina, J.A., Velilla, J., 2020. Commuting and self-employment in Western Europe. J. Transport Geogr. 88, 102856.

Gimenez-Nadal, J.I., Molina, J.A., Velilla, J., 2018b. Spatial distribution of US employment in an urban efficiency wage setting. J. Reg. Sci. 58 (1), 141-158.

Goerke, L., Lorenz, O., 2017. Commuting and Sickness Absence. IZA Discussion. Paper No. 11183

Gordon, P., Kumar, A., Richardson, H.W., 1989. Gender differences in metropolitan travel behaviour. Reg. Stud. 23 (6), 499-510.

Gossen, R., Purvis, C., 2005. Activities, time, and travel: changes in women's travel time expenditures, 1990-2000. In: Research of Women's Issues in Transportation, vol. 2. National Research Council, Washington, DC. Technical Papers, Transportation Research Board Conference Proceedings 35.

Gottholmseder, G., Nowotny, K., Pruckner, G.J., Theurl, E., 2009. Stress perception and commuting. Health Econ. 18, 559-576.

Grieco, M., Pickup, L., Whipp, R., 1989. Gender, Transport and Employment: the Impac of Travel Constraints. Gower Publishing Company, Aldershot.

Grinza, E., Rycx, F., 2020. The impact of sickness absenteeism on ffirm productivity: new evidence from Belgian matched employer-employee panel data. Ind. Relat.: J. Econ. Soc. 59 (1), 150-194.

Hamilton, B.W., 1982. Wasteful commuting. J. Polit. Econ. 90 (5), 1035-1053.

Hamilton, B.W., 1989. Wasteful commuting again. J. Polit. Econ. 97 (6), 1497-1504.

Hanson, S., Johnston, I., 1985. Gender differences in work trip lengths: implications and explanations. Urban Geogr. 6 (3), 193-219.

Hansson, E., Mattisson, K., Björk, J., Östergren, P.O., Jakobsson, K., 2011. Relationship between commuting and health outcomes in a cross-sectional population survey in southern Sweden. BMC Publ. Health 11 (1), 834.

Harms, T., Berrigan, D., Gershuny, J., 2019. Daily metabolic expenditures: estimates from US, UK and polish time-use data. BMC Publ. Health 19 (2), 453.

Hilbrecht, M., Smale, B., Mock, S.E., 2014. Highway to health? Commute time and well being among Canadian adults. World Leisure J. 56 (2), 151-163.

Hjorthol, R., 2008. Daily mobility of men and women - a barometer of gender equality. Gendered Mobilities 193-210.

Hjorthol, R., Vågane, L., 2014. Allocation of tasks, arrangement of working hours and commuting in different Norwegian households. J. Transport Geogr. 35, 75-83.

Jara-Díaz, S., Rosales-Salas, J., 2015. Understanding time use: daily or weekly data? Transport. Res. Pol. Pract. 76 (1), 38-57.

Kahn, M.E., 2000. The environmental impact of suburbanization. J. Pol. Anal. Manag. 19 (4), 569-586.

Kahneman, D., Krueger, A.B., 2006. Developments in the measurement of subjective well-being. J. Econ. Perspect. 20 (1), 3-24.

Kahneman, D., Krueger, A.B., Schkade, D.A., Schwarz, N., Stone, A.A., 2004. A survey method for characterizing daily life experience: the day reconstruction method. Science 306 (5702), 1776-1780.

Kain, J.F., 1962. The journey-to-work as a determinant of residential location. Pap. Proc Reg. Sci. Assoc. 9, 137-160.

Katz, L.F., Murphy, K.M., 1992. Changes in relative wages, 1963-1987: supply and demand factors. Q. J. Econ. 107 (1), 35-78.

Kirby, D.K., LeSage, J.P., 2009. Changes in commuting to work times over the 1990 to 2000 period. Reg. Sci. Urban Econ. 39 (4), 460-471.

Kroesen, M., 2014. Assessing mediators in the relationship between commute time and subjective well-being: structural equation analysis. Transport. Res. Rec. 2452 (1), 114-123.

Kunn-Nelen, A., 2016. Does commuting affect health? Health Econ. 25 (8), 984-1004.

Le Barbanchon, T., Rathelot, R., Roulet, A., 2019. Gender Differences in Job Search: Trading off Commute against Wage. SSRN 3467750.

Lee, B.S., McDonald, J.F., 2003. Determinants of commuting time and distance for Seoul residents: the impact of family status on the commuting of women. Urban Stud. 40 (7), 1283-1302.
Leigh, J.P., 1986. Are compensating wages paid for time spent commuting? Appl. Econ. 18 (11), 1203-1214.

Manning, A., 2003. The real thin theory: monopsony in modern labour markets. Lab. Econ. 10 (2), 105-131.

McKenzie, B., Rapino, M., 2009. Commuting in the United States: 2009. US Department of Commerce, Economics and Statistics Administration, US Census Bureau, Washington, DC.

McQuaid, R.W., Chen, T., 2012. Commuting times: the role of gender, children and parttime work. Res. Transport. Econ. 34 (1), 66-73.

Mieszkowski, P., Mills, E.S., 1993. The causes of metropolitan suburbanization. J. Econ. Perspect. 7 (3), 135-147.

Mitra, S.K., Saphores, J.D.M., 2019. Why do they live so far from work? Determinants of long-distance commuting in California. J. Transport Geogr. 80, 102489.

Mok, D., 2007. Do two-earner household base their choice of residential location on both incomes? Urban Stud. 44 (4), 723-750.

Moss, J.E., Jack, C.G., Wallace, M.T., 2004. Employment location and associated commuting patterns for individuals in disadvantaged rural areas in Northern Ireland. Reg. Stud. 38 (2), 121-136.

Mulalic, I., Van Ommeren, J.N., Pilegaard, N., 2014. Wages and commuting: quasinatural experiments' evidence from firms that relocate. Econ. J. 124 (579), 1086-1105.

Naess, P., 2003. Urban structures and travel behaviour. Eur. J. Transport Infrastruct. Res. 3 (2), 155-178.

Naess, P., 2006. Urban Structure Matters: Residential Location, Car Dependence and Travel Behaviour. Routledge.

Naess, P., 2009. Residential self-selection and appropriate control variables in land use: travel studies. Transport Rev. 29 (3), 293-324.

Naess, P., Sandberg, S.L., 1996. Workplace location, modal split and energy use for commuting trips. Urban Stud. 33 (3), 557-580.

Naess, P., Strand, A., Wolday, F., Stefansdottir, H., 2019a. Residential location, commuting and non-work travel in two urban areas of different size and with different center structures. Prog. Plann. 128, 1-36.

Naess, P., Tønnesen, A., Wolday, F., 2019b. How and why does intra-metropolitan workplace location affect car commuting? Sustainability 11 (4), 1196.

Nafilyan, V., 2019. Gender Differences in Commute Time and Pay: A Study into the Gender Gap for Pay and Commuting Time, Using Data from the Annual Survey of Hours and Earnings. Office for National Statistics, United Kingdom.

Ng, W., Acker, A., 2018. Understanding Urban Travel Behaviour by Gender for Efficient and Equitable Transport Policies. ITF Discussion Paper 2018-01.

Novaco, R.W., Gonzalez, O.I., 2009. Commuting and well-being. In: AmichaiHamburger, Y. (Ed.), Technology and Psychological Well-Being. Cambridge University Press, Cambridge, U.K., pp. 174-205

Oakil, A.T.M., Nijland, L., Dijst, M., 2016. Rush hour commuting in The Netherlands: gender-specific household activities and personal attitudes towards responsibility sharing. Travel Behav. Soc. 4, 79-87.

O'Kelly, M.E., Niedzielski, M.A., Gleeson, J., 2012. Spatial interaction models from Irish commuting data: variations in trip length by occupation and gender. J. Geogr. Syst. 14 (4), 357-387.

Ramey, G., Ramey, V.A., 2010. The rug rat race. Brookings Pap. Econ. Activ. 41 (1), 129-199.

Roberts, J., Hodgson, R., Dolan, P., 2011. It's driving her mad: gender differences in the effects of commuting on psychological health. J. Health Econ. 30 (5), 1064-1076.

Robinson, J.P., 1985. The validity and reliability of diaries versus alternative time use measures. In: Juster, F.T., Stafford, F.P. (Eds.), Time, Goods, and Well-Being. The University of Michigan, Ann Arbor, MI, pp. 33-62.

Rodríguez, D.A., 2004. Spatial choices and excess commuting: a case study of bank tellers in Bogotá, Colombia. J. Transport Geogr. 12 (1), 49-61.

Ross, S.L., Zenou, Y., 2008. Are shirking and leisure substitutable? An empirical test of efficiency wages based on urban economic theory. Reg. Sci. Urban Econ. 38 (5), 498-517.

Rouwendal, J., Nijkamp, P., 2004. Living in two worlds: a review of home-to-work decisions. Growth Change 35 (3), 287-303.

Rouwendal, J., Rietveld, P., 1994. Changes in commuting distances of Dutch households. Urban Stud. 31 (9), 1545-1557.

Ruppert, P., Stancanelli, E., Wasmer, E., 2009. Commuting, wages and bargaining power. Ann. Econ. Stat. 95/96, 201-220.

Sandow, E., 2008. Commuting behaviour in sparsely populated areas: evidence from northern Sweden. J. Transport Geogr. 16 (1), 14-27.

Sandow, E., Westin, K., 2010. Preferences for commuting in sparsely populated areas: the case of Sweden. J. Transport Land Use 2 (3/4), 87-107.

Santos, G., Maoh, H., Potoglou, D., von Brunn, T., 2013. Factors influencing modal split of commuting journeys in medium-size European cities. J. Transport Geogr. 30 (1), 127-137.

Scheiner, J., 2010. Social inequalities in travel behaviour: trip distances in the context of residential self-selection and lifestyles. J. Transport Geogr. 18 (6), 679-690.

Scheiner, J., 2017. Women's complex daily lives: a gendered look at trip chaining and activity pattern entropy in Germany. Transportation 44 (1), 117-138.

Scheiner, J., Holz-Rau, C., 2012. Gender structures in car availability in car deficient households. Res. Transport. Econ. 34 (1), 16-26.

Small, K.A., Song, S., 1992. Wasteful commuting: a resolution. J. Political Acon. 100 (4), 888-898.

Susilo, Y.O., Maat, K., 2007. The influence of built environment to the trends in commuting journeys in The Netherlands. Transportation 34 (5), 589-609.

Timothy, D., Wheaton, W.C., 2001. Intra-urban wage variation, employment location, and commuting times. J. Urban Econ. 50 (2), 338-366. 
Tobin, J., 1958. Estimation of relationships for limited dependent variables. Econometrica 26 (1), 24-36.

Turner, T., Niemeier, D., 1997. Travel to work and household responsibility: new evidence. Transportation 24 (4), 397-419.

Van Acker, V., Witlox, F., 2011. Commuting trips within tours: how is commuting related to land use? Transportation 38 (3), 465-486.

Van den Berg, G.J., Gorter, C., 1997. Job search and commuting time. J. Bus. Econ. Stat. 15 (2), 269-281.

Van Ommeren, J.N., Gutiérrez-i-Puigarnau, E., 2011. Are workers with a long commute less productive? An empirical analysis of absenteeism. Reg. Sci. Urban Econ. 41 (1), $1-8$.

Van Ommeren, J.N., Van der Straaten, J.W., 2008. The effect of search imperfections on commuting behavior: evidence from employed and self-employed workers. Reg. Sci. Urban Econ. 38 (2), 127-147.

Van Ommeren, J., Rietveld, P., Nijkamp, P., 1999. Job moving, residential moving and commuting: a search perspective. J. Urban Econ. 46, 230-253.
Vandersmissen, M., Thériault, M., Villenueve, P., 2006. Work trips: are there still gender differences? The case of the Quebec metropolitan area. In: Paper at the Transportation Research Board Annual Conference, Washington, D.C.

Wener, R.E., Evans, G.W., Phillips, D., Nadler, N., 2003. Running for the 7:45: the effects of public transit improvements on commuter stress. Transportation 30, 203-220.

Wheatley, D., 2014. Travel-to-work and subjective well-being: a study of UK dual career households. J. Transport Geogr. 39, 187-196.

White, M.J., 1986. Sex differences in urban commuting patterns. Am. Econ. Rev. 76 (2), 368-372.

Wooldridge, J.M., 2016. Introductory Econometrics: A Modern Approach. Nelson Education.

Worx, S.D., 2018. More than $20 \%$ of Europeans commute at least 90 minutes daily. Available at: https://www.sdworx.com/en/press/2018/2018-09-20-more-than20percent-of-europeans-commute-at-least-90-minutes-daily.

Yee-Kan, M., 2008. Measuring housework participation: the gap between "stylised" questionnaire estimates and diary-based estimates. Soc. Indicat. Res. 86 (3), $381-400$. 